\title{
Fundamentals of Cellular Calcium Signaling: A Primer
}

\author{
Martin D. Bootman ${ }^{1}$ and Geert Bultynck ${ }^{2}$ \\ ${ }^{1}$ School of Life, Health and Chemical Sciences, The Open University, Milton Keynes MK7 6AA, United Kingdom \\ ${ }^{2}$ Laboratory of Molecular and Cellular Signaling, Department of Cellular and Molecular Medicine, KU Leuven, \\ B-3000 Leuven, Belgium \\ Correspondence: martin.bootman@open.ac.uk
}

Ionized calcium $\left(\mathrm{Ca}^{2+}\right)$ is the most versatile cellular messenger. All cells use $\mathrm{Ca}^{2+}$ signals to regulate their activities in response to extrinsic and intrinsic stimuli. Alterations in cellular $\mathrm{Ca}^{2+}$ signaling and/or $\mathrm{Ca}^{2+}$ homeostasis can subvert physiological processes into driving pathological outcomes. Imaging of living cells over the past decades has demonstrated that $\mathrm{Ca}^{2+}$ signals encode information in their frequency, kinetics, amplitude, and spatial extent. These parameters alter depending on the type and intensity of stimulation, and cellular context. Moreover, it is evident that different cell types produce widely varying $\mathrm{Ca}^{2+}$ signals, with properties that suit their physiological functions. This primer discusses basic principles and mechanisms underlying cellular $\mathrm{Ca}^{2+}$ signaling and $\mathrm{Ca}^{2+}$ homeostasis. Consequently, we have cited some historical articles in addition to more recent findings. A brief summary of the core features of cellular $\mathrm{Ca}^{2+}$ signaling is provided, with particular focus on $\mathrm{Ca}^{2+}$ stores and $\mathrm{Ca}^{2+}$ transport across cellular membranes, as well as mechanisms by which $\mathrm{Ca}^{2+}$ signals activate downstream effector systems.

\section{GENERAL PRINCIPLES OF CELLULAR $\mathrm{Ca}^{2+}$ SIGNALING}

key principle of $\mathrm{Ca}^{2+}$ signaling is that a
change of the intracellular $\mathrm{Ca}^{2+}$ concentra-
tion provokes a cellular response (Berridge et al.
2000). In unstimulated cells, the cytosolic $\mathrm{Ca}^{2+}$
concentration is maintained at $\sim 100 \mathrm{~nm}$ (often
referred to in the $\mathrm{Ca}^{2+}$ signaling literature as the
"resting" or "basal" $\mathrm{Ca}^{2+}$ concentration). Extrin-
sic stimulation of cells can take many forms-
hormonal, neurotransmitter, growth factor,
antibody, mechanical, electrical, gasotransmit-
ter, temperature, pH change, osmotic change, cytotoxic reagents, microbial invasion, and gap junction-mediated passage of cellular signalsall of which have been shown to elevate cytosolic $\mathrm{Ca}^{2+}$ concentration. Alternatively, $\mathrm{Ca}^{2+}$ signaling can occur because of intrinsic cellular cues, such as the spontaneous $\mathrm{Ca}^{2+}$ signals within cardiac myocytes (Hüser et al. 2000) and developing neurons (Ciccolini et al. 2003).

Typically, stimulation of cells leads to an acute increase in cytosolic $\mathrm{Ca}^{2+}$ concentration from the resting level of $100 \mathrm{~nm}$, and at the end of stimulation the $\mathrm{Ca}^{2+}$ concentration returns back to the resting state. The level of cytosolic $\mathrm{Ca}^{2+}$ attained depends on the nature of the

Editors: Geert Bultynck, Martin D. Bootman, Michael J. Berridge, and Grace E. Stutzmann

Additional Perspectives on Calcium Signaling available at www.cshperspectives.org

Copyright $\odot 2020$ Cold Spring Harbor Laboratory Press; all rights reserved; doi: 10.1101/cshperspect.a038802

Cite this article as Cold Spring Harb Perspect Biol 2020;12:a038802 
M.D. Bootman and G. Bultynck

stimulus, as well as factors such as the concentration, intensity and duration of the stimulus, and presence of $\mathrm{Ca}^{2+}$-buffering proteins (Schwaller 2010) and respiring mitochondria (Wacquier et al. 2019). If the cytosolic $\mathrm{Ca}^{2+}$ concentration is monitored by taking an average measure across a whole cell, as is often done using $\mathrm{Ca}^{2+}$-sensitive fluorescent indicators such as Fura-2 (Bootman et al. 2013), $\mathrm{Ca}^{2+}$ signals typically reach peak levels of $0.5-1 \mu \mathrm{M}$ (Fig. 1).

Averaged cytosolic $\mathrm{Ca}^{2+}$ signals $>1 \mu \mathrm{M}$ have been recorded, but such large elevations of $\mathrm{Ca}^{2+}$ concentration require a substantial movement of $\mathrm{Ca}^{2+}$ into the cytosol to counteract the energy-dependent homeostatic $\mathrm{Ca}^{2+}$ clearance mechanisms employed by cells. Such excessive $\mathrm{Ca}^{2+}$ signals are often caused by cellular damage, and are generally considered to be in a nonphysiological range. Large elevations of cytosolic $\mathrm{Ca}^{2+}$ concentration can lead to a variety of deleterious cellular effects, particularly if they are sustained for minutes, because of the activation of $\mathrm{Ca}^{2+}$-dependent proteases, production of reactive oxygen species, acute organelle remodeling, and mitochondrial permeability transition (Orrenius et al. 2003). Examples of the dis- astrous cellular effects of large $\mathrm{Ca}^{2+}$ elevations include excitotoxic stimulation of neurons (Vergun et al. 1999) and death of vascular smooth muscle cells exposed to naturally occurring calcified particles (Proudfoot 2019). However, it is not only large elevations of $\mathrm{Ca}^{2+}$ concentration that are linked to poor cellular outcomes. Indeed, $\mathrm{Ca}^{2+}$ is implicated in numerous pathologies (Parys and Bultynck 2018) as well as in processes underlying natural aging (Verkhratsky 2019). In many cases, subtle alterations of $\mathrm{Ca}^{2+}$ signaling mediate functional or phenotypic changes (Berridge 2012, 2017). The discussion above alludes to the precarious position of cells with regard to $\mathrm{Ca}^{2+}$ signaling. On one hand, $\mathrm{Ca}^{2+}$ is a dynamic and versatile signal within cells, whereby the chemistry of $\mathrm{Ca}^{2+}$ makes it more suitable than other ions for this purpose (Clapham 2007). On the other hand, too much, too little, or misappropriate $\mathrm{Ca}^{2+}$ signaling will ultimately affect cell behavior and fate (Mekahli et al. 2011; Giorgi et al. 2018a).

Understanding the principles underlying $\mathrm{Ca}^{2+}$ dynamics in health and their perturbation in disease and aging also presents unique opportunities to develop strategies to restore normal

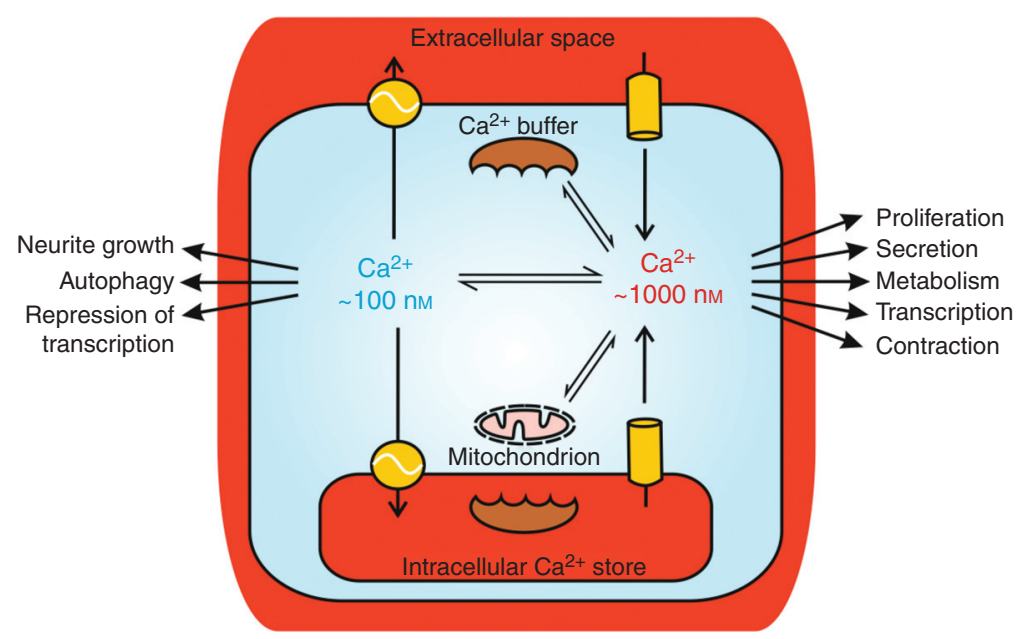

Figure 1. Cytosolic $\mathrm{Ca}^{2+}$ signals arise via $\mathrm{Ca}^{2+}$ release from intracellular organelles and/or $\mathrm{Ca}^{2+}$ influx across the plasma membrane. During physiological $\mathrm{Ca}^{2+}$ signaling, the averaged cytosolic $\mathrm{Ca}^{2+}$ concentration typically increases from $\sim 100 \mathrm{~nm}$ to $\sim 1 \mu \mathrm{M}$, depending on the stimulus and factors such as buffering of $\mathrm{Ca}^{2+}$ by mitochondria and $\mathrm{Ca}^{2+}$-binding proteins. Cellular processes are specifically switched on or off when the cytosolic $\mathrm{Ca}^{2+}$ concentration is altered. The main intracellular $\mathrm{Ca}^{2+}$ store is the endoplasmic reticulum (ER), but also the nuclear envelope, Golgi, and acidic compartments such as lysosomes function as $\mathrm{Ca}^{2+}$ stores (see text). 
cell function, which is a central theme in regenerative medicine. Therefore, researchers have turned their focus on studying $\mathrm{Ca}^{2+}$ signaling in regeneration, for example, using organisms and model systems with a powerful inherent regenerative capacity, such as planarian flatworms (Marchant 2019).

$\mathrm{Ca}^{2+}$ is often regarded as a signal when its cytosolic concentration is elevated. Indeed, $\mathrm{Ca}^{2+}$ has many dramatic effects within cells when its concentration is increased. However, it is important to remember that the absence of $\mathrm{Ca}^{2+}$ elevation (i.e., the resting $\mathrm{Ca}^{2+}$ concentration), may also have a signaling function because some processes within cells are inhibited by an elevation of cytosolic $\mathrm{Ca}^{2+}$ concentration. For example, the transcriptional repressor downstream regulatory element antagonist modulator (DREAM) binds to target genes and prevents their transcription at resting $\mathrm{Ca}^{2+}$ concentration (Hagenston et al. 2019). In addition, neurite outgrowth has been negatively correlated with $\mathrm{Ca}^{2+}$ signaling in some neuronal cell types (Mattson et al. 1988). A lack of $\mathrm{Ca}^{2+}$ signaling can trigger processes such as quiescence (a reversible growth/ proliferation arrest) (Humeau et al. 2018) or autophagy, a lysosomal turnover pathway responsible for the clearance of damaged or unwanted proteins and organelles (Bootman et al. 2018). Consequently, it should be remembered that $\mathrm{Ca}^{2+}$ signals have pleiotropic actions within cells: some processes will be switched on, while others are switched off, when the cytosolic $\mathrm{Ca}^{2+}$ concentration is elevated. The cellular effect of $\mathrm{Ca}^{2+}$ signaling also depends on the context of a cell in terms of its position in the cell cycle, energetic status, and other incoming external signaling cues. All of the above paints a complex picture of cellular responses to stimuli that evoke cytosolic $\mathrm{Ca}^{2+}$ signals. Indeed, it is this complexity, coupled with a desire to understand how specific cell types generate their individualistic $\mathrm{Ca}^{2+}$ signals, which sustains the interest of the many laboratories around the world who study signal transduction by $\mathrm{Ca}^{2+}$.

Cells can access two principal sources of $\mathrm{Ca}^{2+}$ to generate signals: $\mathrm{Ca}^{2+}$ release from intracellular stores and $\mathrm{Ca}^{2+}$ influx from the extracellular space (Fig. 1). Both of these $\mathrm{Ca}^{2+}$ sources are utilized by cells, but the balance between the two can differ. For example, cytosolic $\mathrm{Ca}^{2+}$ signals mediate contraction of both skeletal and cardiac muscle by activating the engagement of actin and myosin fibers (Santulli et al. 2017). However, skeletal muscle cells can continue to contract for some time in the absence of extracellular $\mathrm{Ca}^{2+}$, whereas cardiac muscle cells will immediately cease contracting if extracellular $\mathrm{Ca}^{2+}$ is withdrawn (Eisner et al. 2017).

$\mathrm{Ca}^{2+}$ release from intracellular stores occurs via channels that span the membranes of organelles. Principal $\mathrm{Ca}^{2+}$ releasing channels are inositol 1,4,5-trisphosphate receptors ( $\mathrm{IP}_{3} \mathrm{Rs}$ ) (Prole and Taylor 2019), ryanodine receptors (RyRs) (Lanner et al. 2010), two-pore channels (TPCs) (Galione 2019; Lloyd-Evans and WallerEvans 2019; Webb et al. 2019), and the mucolipin subfamily of transient receptor potential channels (TRPML) (Vangeel and Voets 2019). The endoplasmic reticulum (ER) in nonexcitable cells and neurons, and the sarcoplasmic reticulum (SR) in muscle cells, have long been known as major intracellular $\mathrm{Ca}^{2+}$ stores that play roles in cellular $\mathrm{Ca}^{2+}$ signaling. However, other organelles-the Golgi, nuclear envelope, lysosomes, and other acidic vesicles-also participate in cellular $\mathrm{Ca}^{2+}$ signals when cells are appropriately stimulated (Fig. 2). These $\mathrm{Ca}^{2+}$ stores contain substantial amounts of $\mathrm{Ca}^{2+}$ through the expression of various $\mathrm{Ca}^{2+}$ transporters (Vandecaetsbeek et al. 2011; Chen et al. 2019; Lloyd-Evans and Waller-Evans 2019) and a range of $\mathrm{Ca}^{2+}$-binding proteins (Wang et al. 2019). Other organelles, notably mitochondria and peroxisomes, also play roles in intracellular $\mathrm{Ca}^{2+}$ signaling, but are not substantial constitutive $\mathrm{Ca}^{2+}$ stores. Both mitochondria and peroxisomes sequester $\mathrm{Ca}^{2+}$ during cytosolic $\mathrm{Ca}^{2+}$ increases. The accumulation of $\mathrm{Ca}^{2+}$ by these organelles serves to limit the amplitude of cytosolic $\mathrm{Ca}^{2+}$ signals, just as cytosolic $\mathrm{Ca}^{2+}$-binding proteins do (Fig. 1; Schwaller 2019; Wacquier et al. 2019). However, the role of these compartments is not just to dampen cytosolic $\mathrm{Ca}^{2+}$ rises. For instance, the uptake of $\mathrm{Ca}^{2+}$ by mitochondria intimately links cellular signaling to metabolism and bioenergetics (Cárdenas et al. 2010) and cell fate (Walter and Hajnóczky 2005). In 
M.D. Bootman and G. Bultynck

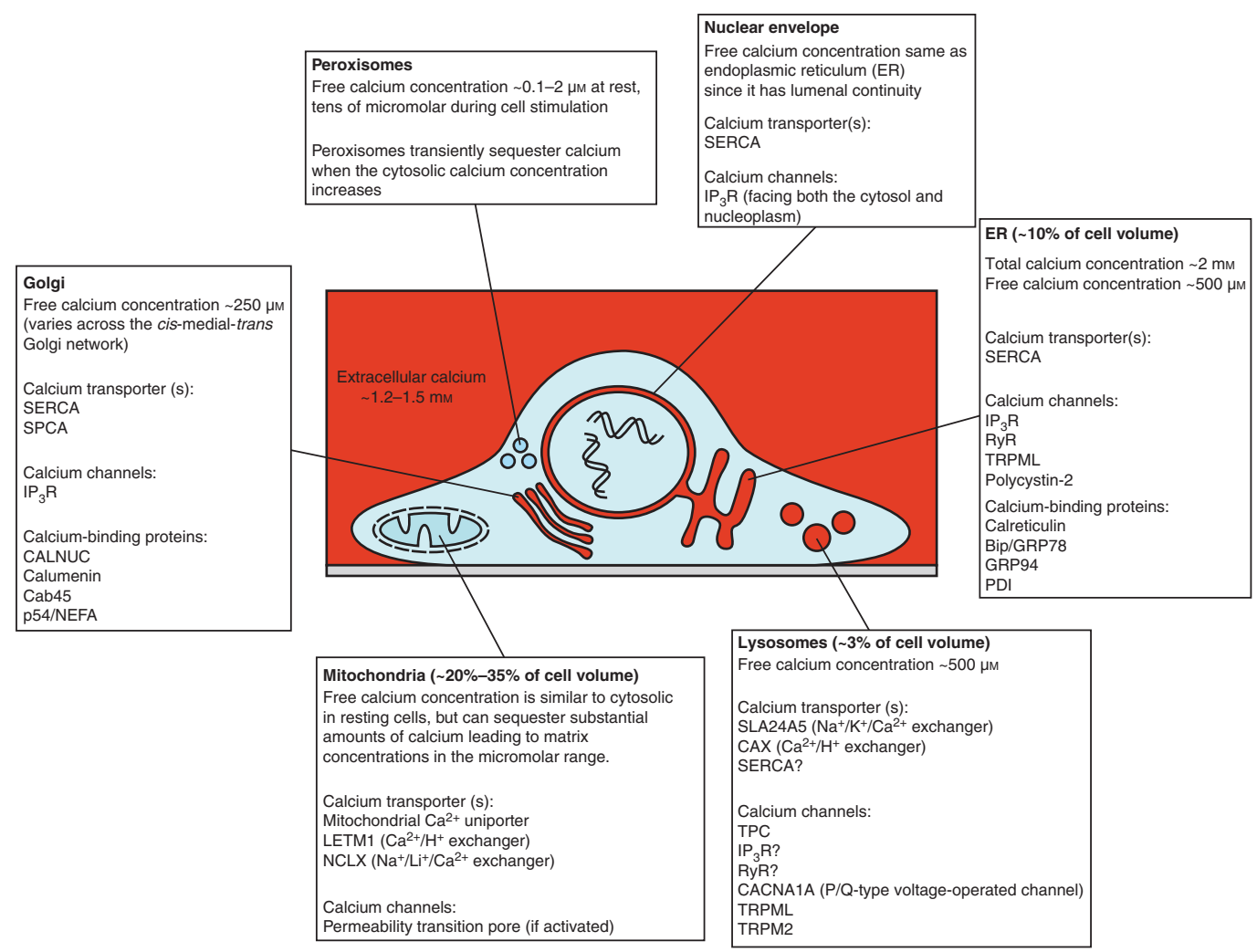

Figure 2. $\mathrm{Ca}^{2+}$-sequestering organelles. Cellular $\mathrm{Ca}^{2+}$ signaling involves combinations of organelles depending on the tissue type and stimulus. Although there is considerable overlap in some of the organelles' characteristics, they also have discrete properties that imbue each of the organelles with the ability to generate distinctive $\mathrm{Ca}^{2+}$ signals. Mitochondria and peroxisomes are not constitutive $\mathrm{Ca}^{2+}$ stores, but have the capacity to sequester $\mathrm{Ca}^{2+}$ during cytosolic $\mathrm{Ca}^{2+}$ increases. For more details, see Wang et al. (2019), Chen et al. (2019), Lloyd-Evans and WallerEvans (2019), Wacquier et al. (2019), and Vangeel and Voets (2019). A significant $\mathrm{Ca}^{2+}$ store not shown in the figures is the sarcoplasmic reticulum (SR), which plays a critical $\mathrm{Ca}^{2+}$ signaling role in muscle cells. For details about SR function and $\mathrm{Ca}^{2+}$ homeostasis see Wang et al. (2019) and Gilbert et al. (2019). SERCA, sarcoendoplasmic reticulum $\mathrm{Ca}^{2+}$-ATPase; SPCA, Golgi/secretory pathway $\mathrm{Ca}^{2+}$ ATPase; TPC, two-pore channel; $\mathrm{IP}_{3} \mathrm{R}$, inositol 1,4,5-trisphosphate receptor; RyR, ryanodine receptor.

the mitochondrial matrix, $\mathrm{Ca}^{2+}$ is a cofactor for some enzymes within the tricarboxylic acid cycle, and promotes ATP production, but can also trigger release of proapoptotic factors (Giorgi et al. 2018b). Moreover, not only does $\mathrm{Ca}^{2+}$ impact mitochondrial metabolism, but mitochondrial metabolism also boosts cellular $\mathrm{Ca}^{2+}$ signaling through regulation of cytosolic $\mathrm{Ca}^{2+}$ signals and redox signaling (Booth et al. 2016; Joseph et al. 2019).

Although organelles may contain sufficient $\mathrm{Ca}^{2+}$ to initiate and sustain signaling for minutes, they are finite $\mathrm{Ca}^{2+}$ stores and will run down if not replenished. Ultimately, $\mathrm{Ca}^{2+}$ from the extracellular space is required to renew organellar $\mathrm{Ca}^{2+}$ and prolong cytosolic $\mathrm{Ca}^{2+}$ signals. However, it should be noted that extracellular $\mathrm{Ca}^{2+}$ can also function to trigger the release of $\mathrm{Ca}^{2+}$ from intracellular stores, as happens in cardiac myocytes (Gilbert et al. 2019), and can directly activate downstream effectors, as happens in neurons (Barak and Parekh 2019; Burgoyne et al. 2019; Hagenston et al. 2019). Indeed, $\mathrm{Ca}^{2+}$ signals arising from organellar $\mathrm{Ca}^{2+}$ release or from $\mathrm{Ca}^{2+}$ influx can have discrete cellular outcomes (Barak and Parekh 2019). 


\section{$\mathrm{ACa}^{2+}$ SIGNALING TOOLKIT}

A simple paradigm that rationalizes the enormous number of components that cells express to generate $\mathrm{Ca}^{2+}$ signals, and respond to them, is that of a toolkit (Berridge et al. 2000). The " $\mathrm{Ca}^{2+}$ signaling toolkit" is essentially all the $\mathrm{Ca}^{2+}$ transporters (channels, pumps, and exchangers), $\mathrm{Ca}^{2+}$-binding proteins, and $\mathrm{Ca}^{2+}$-dependent effectors that exist in nature. From this vast toolkit, cells express the components that fit their function. For example, cardiac myocytes express a specific set of proteins-voltage-operated $\mathrm{Ca}^{2+}$ channels, RyRs, sodium-calcium exchangers, SERCA2a, and troponin $\mathrm{C}-$ that enable them to generate $\mathrm{Ca}^{2+}$ signals that rise and recover within tens of milliseconds, and so trigger pulsatile cellular contraction to pump blood (Bers 2008; Fearnley et al. 2011). In the average human lifetime, cardiac myocytes beat over 2 billion times, and are activated every second by an action potential arriving from the sinoatrial node, so they need to have the ability to rapidly respond and recover with great fidelity. Missing a beat is not an option! In contrast, oocytes are largely dormant cells, waiting for sperm to trigger $\mathrm{Ca}^{2+}$ signaling, cause resumption of the cell cycle, and initiate development (Wakai et al. 2019). Mammalian oocytes express different components from the $\mathrm{Ca}^{2+}$ signaling toolkit$\mathrm{IP}_{3} \mathrm{Rs}$ and SERCA2b-and following fertilization they display a series of long-lasting $\mathrm{Ca}^{2+}$ oscillations with much slower kinetics than the rapid $\mathrm{Ca}^{2+}$ transients observed in cardiomyocytes. Elucidating the specific $\mathrm{Ca}^{2+}$ signaling toolkit components that are discretely expressed by each tissue type, and how they collectively shape $\mathrm{Ca}^{2+}$ signal generation and cellular outcomes, is the key to understanding signal transduction via $\mathrm{Ca}^{2+}$.

It is important to note that the $\mathrm{Ca}^{2+}$ signaling components expressed by cells can be remodeled because of environmental factors or genetic mutation. A well-known example occurs during hypertrophic growth of cardiac myocytes. Hypertrophic stimuli cause an increase in the amplitude of cytosolic $\mathrm{Ca}^{2+}$ signals and larger myocyte contraction (Harzheim et al. 2009), which is a necessary compensation for greater hemodynamic demand, for example, during pregnancy or athletic training. However, in some deleterious situations (e.g., hypertension) hypertrophy can progress to a maladapted state in which $\mathrm{Ca}^{2+}$ signals are reduced, and the heart becomes weaker (Roderick et al. 2007). Moreover, the altered expression or mutation of the $\mathrm{Ca}^{2+}$ signaling toolkit components can lead to oncogenesis and malignant cellular behavior, as is observed in several cancer types (Distelhorst and Bootman 2019; RobertsThomson et al. 2019).

\section{IP $_{3}$ Rs AS AN EXAMPLE OF A CELLULAR SIGNALING HUB}

There are too many components in the $\mathrm{Ca}^{2+}$ signaling toolkit to describe in this limited primer, but some elements are so widely expressed and commonly involved in the generation of $\mathrm{Ca}^{2+}$ signals that they deserve a mention. In particular, $\mathrm{IP}_{3} \mathrm{Rs}$, which are a principal means of releasing $\mathrm{Ca}^{2+}$ from intracellular organelles, participate in $\mathrm{Ca}^{2+}$ signaling within many excitable and nonexcitable cell types (Foskett et al. 2007; Mikoshiba 2015). $\mathrm{IP}_{3}$ Rs are activated following the production of the intracellular messenger $\mathrm{IP}_{3}$ and release $\mathrm{Ca}^{2+}$ from the ER, Golgi, and nuclear envelope (Prole and Taylor 2019), as well as activating a small number of $\mathrm{IP}_{3}$ Rs that are localized at the plasma membrane (Dellis et al. 2006). $\mathrm{IP}_{3}$ production within cells is triggered by a variety of extrinsic stimuli (e.g., hormones, growth factors) that bind to cell-surface receptors (e.g., G-protein-coupled receptors or receptor tyrosine kinases). Application of these stimuli typically induces $\mathrm{Ca}^{2+}$ signals inside cells within a few seconds (Berridge and Galione 1988). As with many components of the $\mathrm{Ca}^{2+}$ signaling toolkit, $\mathrm{IP}_{3}$-mediated $\mathrm{Ca}^{2+}$ release is far from simply being a discrete linear pathway. Indeed, the phosphoinositide signaling pathway (a name commonly used to denote the production of $\mathrm{IP}_{3}$ and activation of $\mathrm{IP}_{3} \mathrm{Rs}$ within cells) is at the center of a web of interactions with other signaling pathways. Phospholipase C (PLC), the enzyme that produces $\mathrm{IP}_{3}$ inside cells (via the hydrolysis of the minor membrane phospholipid phosphatidylinositol 4,5-bisphosphate 
M.D. Bootman and G. Bultynck

$\left.\left[\mathrm{PIP}_{2}\right]\right)$, is expressed as several isoforms, and only some (e.g., PLC- $\beta$, PLC- $\gamma$ ) are activated by extrinsic stimuli. Other isoforms are activated by $\mathrm{Ca}^{2+}$ (most PLCs, but especially PLC- $\delta$ and PLC- $\eta$ ), the small G-protein Ras (PLC- $\varepsilon$ ), or introduced into oocytes by sperm at fertilization (PLC- $\zeta$ ) (Fig. 3). Besides producing $\mathrm{IP}_{3}$, the hydrolysis of $\mathrm{PIP}_{2}$ by PLC yields diacylglycerol (DAG) that stays within the plasma membrane. DAG can activate protein kinase $\mathrm{C}$ (often in cooperation with $\mathrm{Ca}^{2+}$ signals) (Lipp and Reither 2011) or can be further metabolized to produce additional cellular messengers such as arachidonic acid.

Profound insights into the activation of $\mathrm{IP}_{3} \mathrm{Rs}$ have been gained via high-resolution structural studies using cryo-electron microscopy (cryo-EM), a major tour de force given the large size of $\mathrm{IP}_{3} \mathrm{R}$ proteins $\left(\mathrm{IP}_{3} \mathrm{Rs}\right.$ are tetramers of $\sim 270 \mathrm{kDa}$ subunits, giving functional channels of $\sim 1100 \mathrm{kDa}$ ) (Fan et al. 2015, 2018; Hamada et al. 2017). Cryo-EM allows the deter- mination of a protein's structure without requiring its crystallization, an advantage compared to $\mathrm{X}$-ray crystallography or nuclear magnetic resonance spectroscopy, since crystallization is particularly challenging for large, membranous proteins. The structural organization of $\mathrm{IP}_{3} \mathrm{Rs}$ is further discussed in Ivanova et al. (2019).

$\mathrm{IP}_{3}$ Rs are known to bind a range of accessory proteins, many of which convey messages to and from other signaling pathways (Prole and Taylor 2019). Some of the accessory proteins associated with $\mathrm{IP}_{3} \mathrm{Rs}$ affect channel opening and $\mathrm{Ca}^{2+}$ release, while others determine $\mathrm{IP}_{3} \mathrm{R}$ degradation, cellular location, or serve to tether additional proteins that do not directly impact on $\mathrm{IP}_{3} \mathrm{R}$ function. An emerging class of $\mathrm{IP}_{3} \mathrm{R}$-associated proteins is the $\mathrm{Bcl}-2$ family, which are critical controllers of apoptotic cell death (Vervliet et al. 2016; Ivanova et al. 2019). As the expression of Bcl-2-family members is altered in cancer, such $\mathrm{IP}_{3} \mathrm{R} / \mathrm{Bcl}$-2-protein complexes form a mechanistic link between $\mathrm{Ca}^{2+}$ signaling and cell

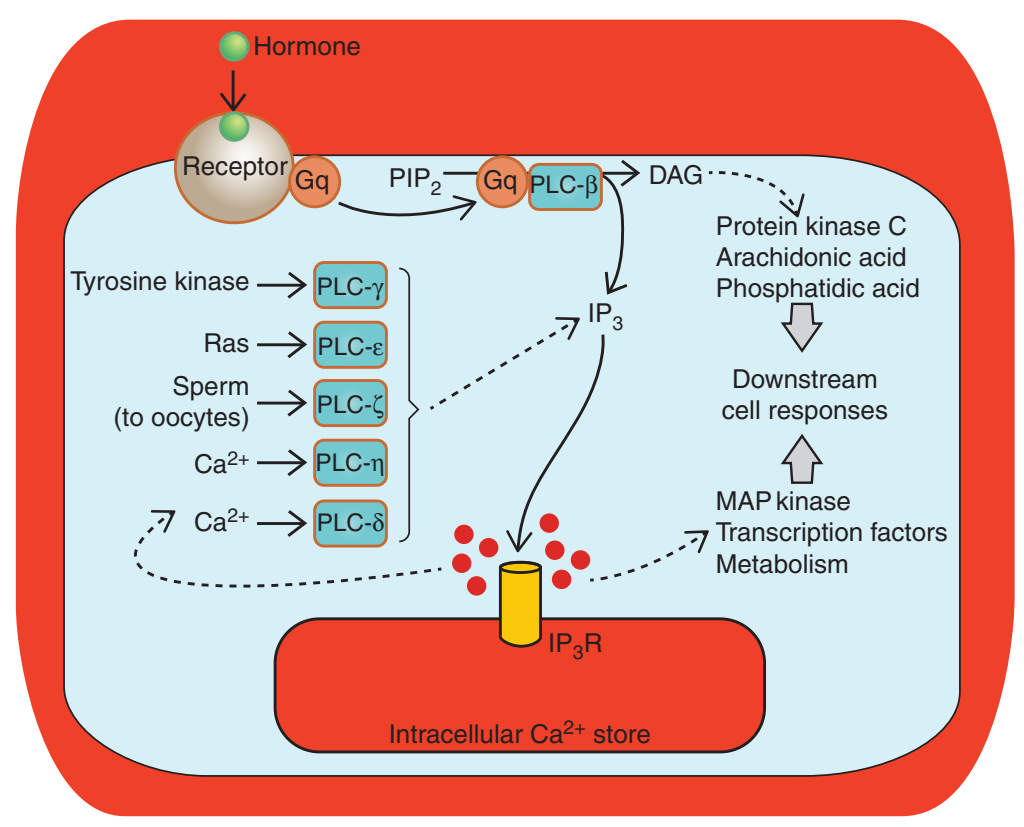

Figure 3. $\mathrm{IP}_{3}$-mediated $\mathrm{Ca}^{2+}$ release is a common outcome from a number of cellular signaling processes and evokes a range of downstream outcomes. A generic pathway leading from hormone-receptor activation, activation of a heterotrimeric G-protein $(\mathrm{Gq})$ and phospholipase $\mathrm{C} \beta(\mathrm{PLC}-\beta)$ is depicted centrally. However, the other $\mathrm{PLC}$ isoforms provide alternative mechanisms for activating $\mathrm{Ca}^{2+}$ signaling via $\mathrm{IP}_{3} \mathrm{Rs}$. (From Bootman et al. 2009; adapted, with permission, from Company of Biologists (c) 2009.) 
death, a pathway that is often dysregulated in cancers but might be therapeutically targeted (Distelhorst and Bootman 2019; Ivanova et al. 2019).

Stimulation of cells with agonists that activate $\mathrm{IP}_{3}$ production typically leads to the generation of cytosolic $\mathrm{Ca}^{2+}$ oscillations (sometimes referred to in the $\mathrm{Ca}^{2+}$ literature as " $\mathrm{Ca}^{2+}$ spikes" or " $\mathrm{Ca}^{2+}$ transients") (Berridge and Galione 1988; Dupont et al. 2011). The patterns of $\mathrm{Ca}^{2+}$ oscillation can vary between cell types, and even within a cell type for different stimuli, but in most cases $\mathrm{Ca}^{2+}$ oscillations are brief increases in cytosolic $\mathrm{Ca}^{2+}$ that last for a few tens of seconds. Generally, $\mathrm{Ca}^{2+}$ oscillations have a rapid rising phase, reaching a peak cytosolic $\mathrm{Ca}^{2+}$ concentration $\sim 500 \mathrm{~nm}$, before more slowly decaying back to the resting basal $\mathrm{Ca}^{2+}$ concentration. It was demonstrated many years ago that intracellular signaling systems display oscillatory activity (Berridge and Rapp 1979), and that cellular $\mathrm{Ca}^{2+}$ signaling in particular was similarly encoded as oscillations (Woods et al. 1986). Studies have shown that both the frequency of $\mathrm{Ca}^{2+}$ oscillations displayed by cells (Rooney et al. 1989) and the downstream cellular responses (Dolmetsch et al. 1998) are proportional to the concentration of stimulus applied. Hence, $\mathrm{Ca}^{2+}$ signaling is often considered as information transmission in a frequency-encoded manner where the successive pulses of cytosolic $\mathrm{Ca}^{2+}$ that arise with each $\mathrm{Ca}^{2+}$ oscillation trigger a cumulative cellular response (Bhattacharyya et al. 2019; Roy and Cyert 2019).

\section{$\mathrm{Ca}^{2+}$ OSCILLATIONS AS A HIGH-FIDELITY SIGNALING MECHANISM}

There are a number of advantages to using oscillatory $\mathrm{Ca}^{2+}$ signals for information transfer within cells. As mentioned earlier, sustained increases in cytosolic $\mathrm{Ca}^{2+}$ are energetically costly as they need to overcome cellular $\mathrm{Ca}^{2+}$ transport processes, and if the $\mathrm{Ca}^{2+}$ elevation is too great it may cause deleterious effects. So, $\mathrm{Ca}^{2+}$ oscillations are energetically more favorable. Additionally, there is considered to be greater fidelity in frequency-encoded signaling systems than those based on graded amplitude changes (Berridge
1997). Moreover, cells have mechanisms for decoding, and responding to, pulsatile increases in $\mathrm{Ca}^{2+}$ in preference to sustained $\mathrm{Ca}^{2+}$ signals (Hajnóczky et al. 1995). An important mechanism by which $\mathrm{Ca}^{2+}$ signals are decoded involves phosphorylation-dependent control of proteins via both kinases and phosphatases that are activated by $\mathrm{Ca}^{2+}$, such as $\mathrm{Ca}^{2+} /$ calmodulin-dependent kinase II and calcineurin (Bhattacharyya et al. 2019; Roy and Cyert 2019). Additionally, the $\mathrm{Ca}^{2+}$-binding protein calmodulin mediates a number of cytosolic and nuclear effects of $\mathrm{Ca}^{2+}$ signals (Hagenston et al. 2019). The mechanism through which cells generate $\mathrm{Ca}^{2+}$ oscillations is still not completely understood, particularly for situations where there is an interval of many tens of seconds, or even minutes, between successive cytosolic $\mathrm{Ca}^{2+}$ increases (Skupin et al. 2008). A common mechanism invoked to explain cytosolic $\mathrm{Ca}^{2+}$ oscillations is based on the feedback of $\mathrm{Ca}^{2+}$ itself on $\mathrm{IP}_{3} \mathrm{Rs}$. Indeed, $\mathrm{IP}_{3} \mathrm{R}$ activation has a "bell-shaped" dependence on cytosolic $\mathrm{Ca}^{2+}$ : relatively low $\mathrm{Ca}^{2+}$ concentrations (250$500 \mathrm{~nm})$ promote $\mathrm{Ca}^{2+}$ release, whereas greater $\mathrm{Ca}^{2+}$ concentrations $(\sim 1 \mu \mathrm{M})$ inhibit $\mathrm{Ca}^{2+}$ release (Bezprozvanny et al. 1991; Prole and Taylor 2019).

Following stimulation of cells with an agonist that activates phospholipase $\mathrm{C}, \mathrm{IP}_{3}$ produced at the plasma membrane will diffuse within the cytosol and bind to its receptor, $\mathrm{IP}_{3} \mathrm{R}$, on intracellular organelles. At first, the $\mathrm{Ca}^{2+}$ signal is limited, but as the cytosolic $\mathrm{Ca}^{2+}$ concentration increases it can feed back in a positive manner to stimulate further $\mathrm{Ca}^{2+}$ release, a process known as $\mathrm{Ca}^{2+}$-induced $\mathrm{Ca}^{2+}$ release (Roderick et al. 2003). However, as the cytosolic $\mathrm{Ca}^{2+}$ concentration continues to increase it will reach the range in which the feedback becomes inhibitory. At that point the $\mathrm{IP}_{3} \mathrm{Rs}$ will close and the cell can then recover back to the resting situation as $\mathrm{Ca}^{2+}$ is transported out the cell and back into the stores (Fig. 4). In this scheme, $\mathrm{IP}_{3}$ Rs require $\mathrm{IP}_{3}$ binding to become activated, but are actually opened and closed by $\mathrm{Ca}^{2+}$ binding to discrete stimulatory and inhibitory sites, respectively. As discussed above, $\mathrm{Ca}^{2+}$ influx plays a part in restoring the $\mathrm{Ca}^{2+}$ content of the stores so that the cell is set for another oscillatory cycle. In fact, 
M.D. Bootman and G. Bultynck

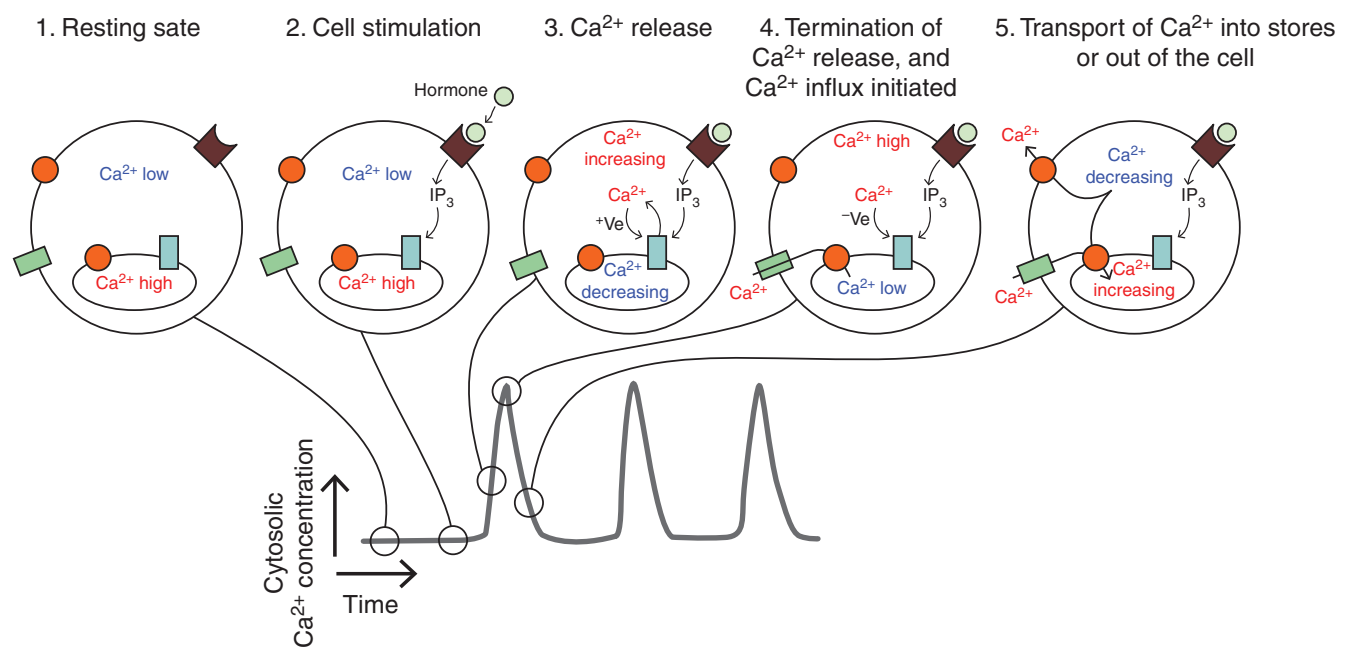

Figure 4. Generation of $\mathrm{Ca}^{2+}$ oscillations via positive and negative feedback on $\mathrm{IP}_{3} \mathrm{Rs}$. The sequence of cartoons 1-5 depict the status of cytosolic $\mathrm{Ca}^{2+}, \mathrm{IP}_{3} \mathrm{R}$ activity, and $\mathrm{Ca}^{2+}$ store content during the various phases of a $\mathrm{Ca}^{2+}$ oscillation. Phase 1 represents the cell at rest, before application of an extracellular stimulus. Phase 2 shows the cell

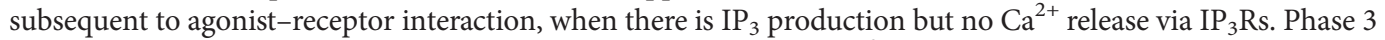
indicates the initial opening of $\mathrm{IP}_{3} \mathrm{Rs}$ and an increasing cytosolic $\mathrm{Ca}^{2+}$ concentration, which exerts a positive $(+\mathrm{Ve})$ feedback on the $\mathrm{IP}_{3} \mathrm{R}$, thereby promoting further $\mathrm{Ca}^{2+}$ release. At phase 4 , the cytosolic $\mathrm{Ca}^{2+}$ concentration has increased to the point where it inhibits $\mathrm{IP}_{3} \mathrm{R}$ activity via negative $(-\mathrm{Ve})$ feedback and hence $\mathrm{Ca}^{2+}$ release terminates. At this point, the $\mathrm{Ca}^{2+}$ store is depleted and $\mathrm{Ca}^{2+}$ influx is activated. Phase 5 indicates the recovery of the cell as $\mathrm{Ca}^{2+}$ is transported from the cytosol toward the intracellular stores and the extracellular environment and the negative feedback from cytosolic $\mathrm{Ca}^{2+}$ is relaxed.

altering the concentration of extracellular $\mathrm{Ca}^{2+}$ has a significant effect on the frequency of cytosolic $\mathrm{Ca}^{2+}$ oscillations, suggesting that the loading of intracellular $\mathrm{Ca}^{2+}$ stores is a key aspect of a cell recovering from one $\mathrm{Ca}^{2+}$ release event to the next (Bootman et al. 1996).

Hormone-evoked $\mathrm{Ca}^{2+}$ oscillations originate in the cytosol through initial activation of clusters of $\mathrm{IP}_{3}$ Rs. Intriguingly, not all $\mathrm{IP}_{3}$ Rs are equal in this respect and only a fraction of the $\mathrm{IP}_{3} \mathrm{Rs}$ that are expressed, specifically those within clusters, seem to be able to respond (Prole and Taylor 2019). The activation of clusters of $\mathrm{IP}_{3} \mathrm{Rs}$ has been visualized using rapid imaging techniques, and the localized cytosolic $\mathrm{Ca}^{2+}$ elevation caused by the activation of an $\mathrm{IP}_{3} \mathrm{R}$ cluster is termed a "Ca ${ }^{2+}$ puff" (Yao et al. 1995; Bootman et al. 1997). With low levels of cell stimulation, and consequently low intracellular levels of $\mathrm{IP}_{3}$, a few $\mathrm{Ca}^{2+}$ puffs may be all that occurs. However, with higher levels of cell stimulation the $\mathrm{Ca}^{2+}$ that diffuses from one cluster of $\mathrm{IP}_{3} \mathrm{Rs}$ during $\mathrm{a} \mathrm{Ca}^{2+}$ puff is likely to encounter a neighboring cluster in which the $\mathrm{IP}_{3} \mathrm{Rs}$ are liganded with $\mathrm{IP}_{3}$. In that case, the second $\mathrm{IP}_{3} \mathrm{R}$ cluster can be triggered and a further $\mathrm{Ca}^{2+}$ puff will occur. Through successive rounds of diffusion and $\mathrm{Ca}^{2+}$-induced $\mathrm{Ca}^{2+}$ release, neighboring $\mathrm{IP}_{3} \mathrm{R}$ clusters can be recruited and $\mathrm{Ca}^{2+}$ signals can propagate throughout a cell. Saltatoric $\mathrm{Ca}^{2+}$ waves, which reflect this fire-diffuse-fire scheme for $\mathrm{Ca}^{2+}$ signal propagation (Thul et al. 2008), have been visualized in the cytosol of a number of cell types including nonexcitable cells (Bootman et al. 1997; Callamaras et al. 1998), cardiac myocytes (Kockskämper et al. 2001), and also the nanotunnels that connect the cytoplasm of adjacent cells (Smith et al. 2011). As $\mathrm{Ca}^{2+}$ waves propagate through cells, they encounter effector proteins that can become activated (Schwaller 2019), as well as other organelles that may sequester, or respond to, the oncoming $\mathrm{Ca}^{2+}$ signal. Moreover, $\mathrm{Ca}^{2+}$ waves can permeate the nucleoplasm by diffusing through nuclear pore 
complexes (Bootman et al. 2009), and thereby modulate gene transcription (Hagenston et al. 2019). As a result of the relative lack of $\mathrm{Ca}^{2+}$ sequestration within the nucleus, $\mathrm{Ca}^{2+}$ increases within this organelle can persist for longer than in the cytosol (Lipp et al. 1997), and indeed have discrete functions (Higazi et al. 2009; Hagenston and Bading 2011).

Although $\mathrm{Ca}^{2+}$ oscillations constitute a form a cell signaling that is used by many cell types for the reasons described above, there are numerous examples of cellular responses being controlled by the amplitude/kinetics (Dolmetsch et al. 1997), or spatial extent, of cytosolic $\mathrm{Ca}^{2+}$ signals (Mackenzie et al. 2004). Indeed, sometimes there is an interplay of different parameters in controlling cellular responses. Within the heart for example, $\beta$-adrenergic receptor stimulation causes higher amplitude $\mathrm{Ca}^{2+}$ signals that contribute to stronger contraction (positive inotropy), faster kinetics for $\mathrm{Ca}^{2+}$ signal recovery (positive lusitropy to enable the heart to relax quicker), and a faster rate of beating (positive chronotropy; although in the intact heart faster beating is caused by more frequent action potentials arising from the sinoatrial node pacemaker).

\section{LOCAL $\mathrm{Ca}^{2+}$ SIGNALS AND MEMBRANE CONTACT SITES ENABLE DISCRETE COMMUNICATION}

Earlier in this article, it was mentioned that averaged $\mathrm{Ca}^{2+}$ signals within cells are typically seen to reach peak levels of $0.5-1 \mu \mathrm{M}$. However, it is important to point out that at the mouth of an open $\mathrm{Ca}^{2+}$ channel (or $\mathrm{Ca}^{2+}$ channel cluster) the concentration of $\mathrm{Ca}^{2+}$ can be reach in excess of $100 \mu \mathrm{M}$ (Thul and Falcke 2004; Demuro and Parker 2006). The concentration of $\mathrm{Ca}^{2+}$ falls dramatically with distance from an active channel, because of dissipation via diffusion and buffering (Thul and Falcke 2004). So, when a cell is stimulated, $\mathrm{Ca}^{2+}$ increases of many tens of micromolar will develop around the locations of the activated $\mathrm{Ca}^{2+}$ channels, and diffusion of $\mathrm{Ca}^{2+}$ away from these channels will yield a more widespread distribution of $\mathrm{Ca}^{2+}$ with a substantially lower $\mathrm{Ca}^{2+}$ concentration. The regions of high $\mathrm{Ca}^{2+}$ concentration around activated $\mathrm{Ca}^{2+}$ channels have been increasingly recognized as having distinct signaling functions (Barak and Parekh 2019; Wang et al. 2019) and are often referred to as " $\mathrm{Ca}^{2+}$ signaling microdomains" (or nanodomains, depending on the distance involved; sometimes the terms " $\mathrm{Ca}^{2+}$ hotspots" or "local $\mathrm{Ca}^{2+}$ signals" are used in the literature). Some $\mathrm{Ca}^{2+}$-sensitive effectors are localized close to $\mathrm{Ca}^{2+}$ channels, thereby providing a means for rapid and specific cellular outcomes (Bootman et al. 2001; Berridge 2006).

$\mathrm{Ca}^{2+}$ signaling microdomains also occur because of the close apposition of cellular organelles (Ahuja et al. 2019), for example, between the ER and mitochondria, the ER and lysosomes, or organelles with the plasma membrane (La Rovere et al. 2016; Raffaello et al. 2016; Csordás et al. 2018). $\mathrm{Ca}^{2+}$ signaling microdomains are a rapidly growing aspect of the wider topic of membrane contact sites in cell biology (Dolgin 2019; Scorrano et al. 2019). The close proximity of organelles and membranes is brought about through tethering proteins (Scorrano et al. 2019), thereby enabling $\mathrm{Ca}^{2+}$ signals originating at one membrane to activate processes at the apposed membrane. These membrane contact sites limit the diffusion of $\mathrm{Ca}^{2+}$ and provide a means for highly specific interactions between $\mathrm{Ca}^{2+}$ sources and effectors. Examples of four different $\mathrm{Ca}^{2+}$ signaling mechanisms in which membrane contact sites are essential are depicted in Figure 5. Although the four examples shown in Figure 5 are all based on the essential apposition of cellular organelles/membranes, they are different in terms of $\mathrm{Ca}^{2+}$ toolkit components and physiological outcomes.

Store-operated $\mathrm{Ca}^{2+}$ entry (SOCE) (Fig. 5A) was postulated many years ago to explain the observation that depletion of intracellular $\mathrm{Ca}^{2+}$ stores led to $\mathrm{Ca}^{2+}$ influx across the plasma membrane (Putney 1990; Ahuja et al. 2019; Lewis 2019). Moreover, a highly $\mathrm{Ca}^{2+}$-selective current was identified that was triggered by $\mathrm{Ca}^{2+}$ store depletion (Hoth and Penner 1992). This current was termed " $\mathrm{Ca}^{2+}$ release-activated current" ( $\left.I_{\text {CRAC }}\right)$ and it is the electrophysiological basis of SOCE. The molecular components of SOCE were established sometime later: stromal inter- 
M.D. Bootman and G. Bultynck

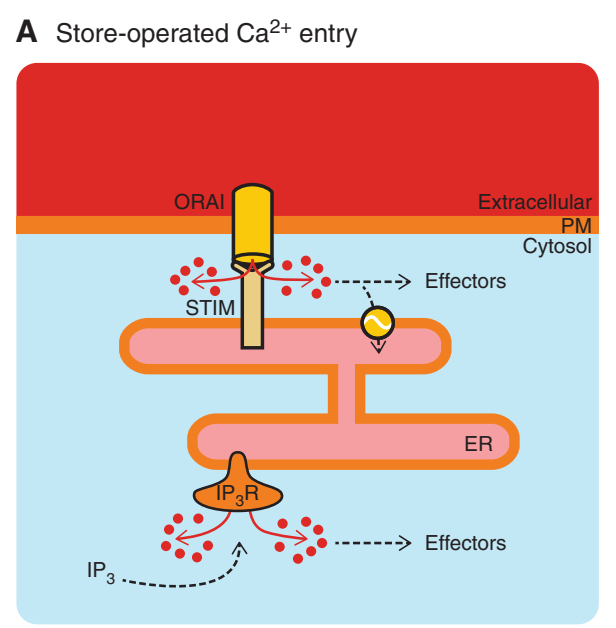

C Mitochondrial $\mathrm{Ca}^{2+}$ uptake

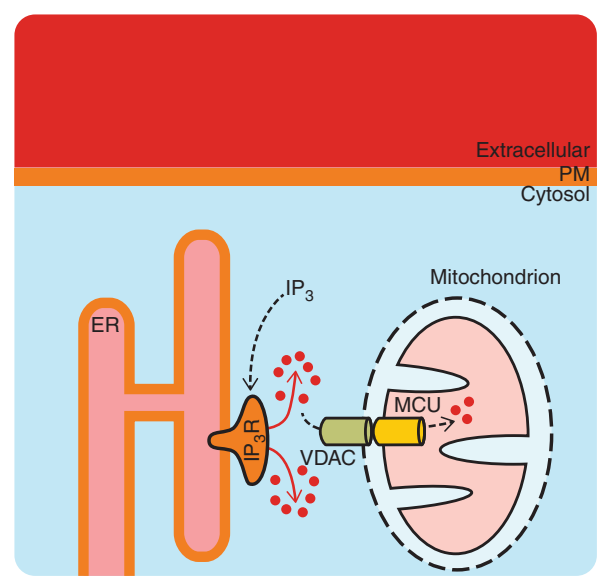

B Cardiac excitation-contraction coupling

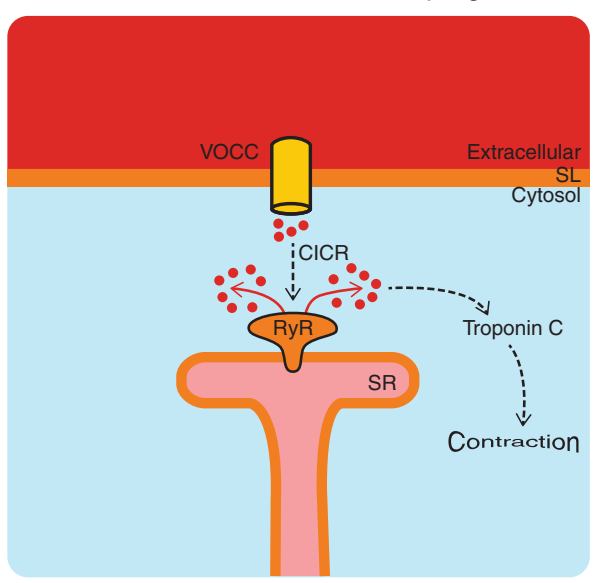

D Triggering $\mathrm{Ca}^{2+}$-induced $\mathrm{Ca}^{2+}$ release

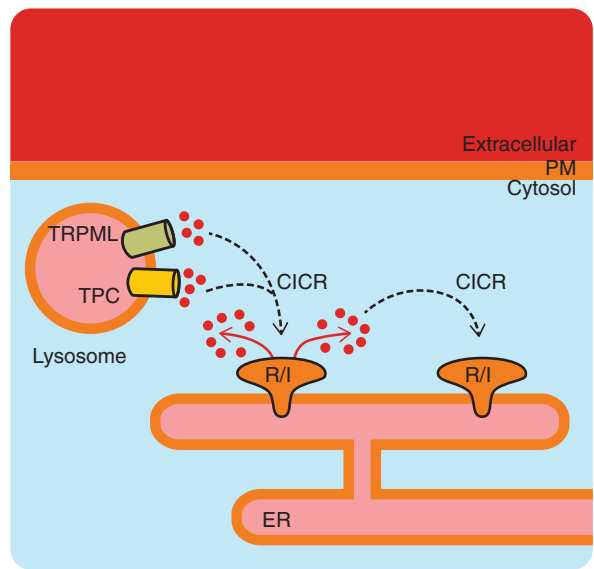

Figure 5. Examples of $\mathrm{Ca}^{2+}$ signaling via membrane contact sites. $(A)-(D)$ Well-known situations where the close apposition of membranes/organelles is essential for initiation or communication of $\mathrm{Ca}^{2+}$ signals. VOCC, voltageoperated $\mathrm{Ca}^{2+}$ channel; SL, sarcolemma; VDAC, voltage-dependent anion channel; MCU, mitochondrial $\mathrm{Ca}^{2+}$ uniporter; TPC, two-pore channel; TRPML, mucolipin subfamily of transient receptor potential channels; CICR, $\mathrm{Ca}^{2+}$-induced $\mathrm{Ca}^{2+}$ release; $\mathrm{R} / \mathrm{I}$, ryanodine receptor or $\mathrm{IP}_{3}$ receptor.

action molecule (STIM), which acts as a sensor of ER luminal $\mathrm{Ca}^{2+}$ loss (Liou et al. 2005; Zhang et al. 2005), and Orai, which forms the $\mathrm{Ca}^{2+}$ channel in the plasma membrane (Prakriya et al. 2006). STIM is a transmembrane protein that spans the ER and projects its carboxy terminus into the cytosol. A substantial amount of work has been focused on understanding how STIM regulates SOCE (Lewis 2019). Briefly, STIM can bind $\mathrm{Ca}^{2+}$ within the lumen of the $\mathrm{ER}$, and if the $\mathrm{Ca}^{2+}$ concentration drops below a threshold level then $\mathrm{Ca}^{2+}$ dissociates from STIM. Consequently, STIM oligomerizes and triggers the opening Orai channels at the plasma membrane (Soboloff and Romanin 2019). The loss of $\mathrm{Ca}^{2+}$ from STIM causes substantial molecular rearrangements within the STIM protein such that its carboxy-terminal domain projects toward Orai channels so that they physically interact. This interaction occurs in regions where the ER and plasma membrane come within $15 \mathrm{~nm}$ of each other (Zhou et al. 2017). 
In addition to Orai, SOCE can be mediated by members of the transient receptor potential (TRP) family, and in particular the subfamily of canonical TRP channels (TRPCs) (Ahuja et al. 2019; Ong and Ambudkar 2019; Vangeel and Voets 2019). Indeed, Orai and TRPC channels can cooperate in the activation of $\mathrm{Ca}^{2+}$ entry (Ambudkar et al. 2017). $\mathrm{Ca}^{2+}$ store depletion and STIM1-Orai interaction leads to the insertion of TRPCs into the plasma membrane. The participation of TRPCs alongside Orai prolongs SOCE and downstream signaling (Cheng et al. 2011). The interaction of STIM1, Orai, and TRPCs gives rise to a current that has been termed $I_{\mathrm{SOC}}$, which is distinct from $I_{\mathrm{CRAC}}$ (Desai et al. 2015). Insights into the properties and mode of TRP activation have been propelled forward by advances in structural information (Vangeel and Voets 2019).

Excitation-contraction coupling in cardiac myocytes (Fig. 5B) also relies on the close apposition of the cell membrane with a major intracellular $\mathrm{Ca}^{2+}$ store, but in this case it is the sarcolemma (the myocyte cell membrane) and the SR (the $\mathrm{Ca}^{2+}$ store within muscle cells that is used to activate contraction). The $\mathrm{Ca}^{2+}$ channels responsible for myocyte contraction are voltageoperated $\mathrm{Ca}^{2+}$ channels (specifically, $\mathrm{Ca}_{\mathrm{V}} 1.2$ or "L-type" voltage-operated $\mathrm{Ca}^{2+}$ channels) on the sarcolemma, and RyRs on the SR. RyRs are primarily activated by $\mathrm{Ca}^{2+}$, but can also respond to cellular messengers such as cyclic adenosine diphosphate ribose (Galione and Churchill 2000).

Blood pumping by the heart occurs via the coordinated contraction of the atrial and ventricular chambers in a process known as the cardiac cycle (Bers 2002). Each cardiac cycle is initiated by a group of specialized pacemaking cells in the right atrial chamber (the sinoatrial node), which spontaneously discharge electrical signals (action potentials) that propagate through the heart. $\mathrm{Ca}^{2+}$ is the cellular messenger that links propagating action potentials and cardiomyocyte contraction (Gilbert et al. 2019). When an action potential arrives at a cardiac myocyte, it triggers a brief depolarization of the sarcolemma, which consequently activates the voltage-operated $\mathrm{Ca}^{2+}$ channels, leading to the influx of $\mathrm{Ca}^{2+}$ from outside of the cells into a membrane-delimited region called the dyadic cleft (Eisner et al. 2017). The sarcolemma and SR come within $10-15 \mathrm{~nm}$ of each other at a dyadic cleft. This proximity is necessary so that the $\mathrm{Ca}^{2+}$ influx through voltage-operated $\mathrm{Ca}^{2+}$ channels can diffuse to the RyRs present on the SR membrane at a concentration sufficient to trigger $\mathrm{Ca}^{2+}$-induced $\mathrm{Ca}^{2+}$ release (Fearnley et al. 2011).

The activation of RyRs leads to a rapid increase of the $\mathrm{Ca}^{2+}$ concentration within the dyadic cleft. The $\mathrm{Ca}^{2+}$ signal within the dyadic cleft subsequently diffuses out into the cytoplasm and encounters troponin C (among other targets), which promotes the association of actin and myosin to trigger cell contraction. A single cardiac myocyte contains thousands of dyadic clefts that simultaneously respond during an action potential, and all contribute to the $\mathrm{Ca}^{2+}$ signal that is required for contraction. It has been suggested that around 25 voltage-operated $\mathrm{Ca}^{2+}$ channels and 100 RyRs are closely apposed within a single dyadic cleft (Bers and Guo 2005). In some cardiac diseases, the sarcolemma and SR membranes become dissociated such that there is no cross talk between voltage-operated $\mathrm{Ca}^{2+}$ channels and RyRs (Louch et al. 2004). These "orphaned RyRs" are not recruited during excitation-contraction coupling, hence myocyte $\mathrm{Ca}^{2+}$ signaling and contraction become weaker (Heinzel et al. 2011).

Mitochondrial $\mathrm{Ca}^{2+}$ uptake (Fig. 5C) relies on the close association of mitochondria to $\mathrm{Ca}^{2+}$ channels. In fact, mitochondria can accumulate $\mathrm{Ca}^{2+}$ from various sources (i.e., $\mathrm{Ca}^{2+}$ release from organelles and $\mathrm{Ca}^{2+}$ influx) (Collins et al. 2001). However, the rate of $\mathrm{Ca}^{2+}$ uptake by mitochondria depends on the proximity of these organelles to $\mathrm{Ca}^{2+}$ channels. It was demonstrated some time ago that mitochondria are relatively insensitive to the average measured cytosolic $\mathrm{Ca}^{2+}$ concentrations that occur during cell stimulation (i.e., 100-500 nм) (Kirichok et al. 2004), and that mitochondrial $\mathrm{Ca}^{2+}$ uptake relies on the microdomains of high $\mathrm{Ca}^{2+}$ concentration that occur close to activated channels (Rizzuto et al. 1993; Csordás et al. 1999). Mitochondria-associated membranes (MAMs) are a specific form 
M.D. Bootman and G. Bultynck

of membrane contact site, and are intensely studied as sites of $\mathrm{Ca}^{2+}$ communication between the ER and mitochondria (in addition to being sites of protein and lipid transfer) (Marchi et al. 2018). This interorganellar complex enables the "quasisynaptic" transfer of $\mathrm{Ca}^{2+}$ between the ER and mitochondria (Rizzuto et al. 1998; Csordás et al. 1999).

Within MAMs, $\mathrm{IP}_{3}$ Rs on the ER membrane are coupled via chaperones with voltage-dependent anion channels (VDACs) situated in the outer mitochondrial membrane (Szabadkai et al. 2006). VDAC proteins permit the passage of $\mathrm{Ca}^{2+}$ across the outer mitochondrial membrane. $\mathrm{Ca}^{2+}$ transport across the inner mitochondrial membrane is enabled by the mitochondrial $\mathrm{Ca}^{2+}$ uniporter complex (Granatiero et al. 2017), which has key roles in cell death (Penna et al. 2018), organ physiology (Mammucari et al. 2018), and disease (Mammucari et al. 2017). Changes in MAM organization have been linked to neurodegenerative diseases and cancer (Kerkhofs et al. 2017; Rossi et al. 2019). Moreover, the cellular sensitivity of cancer cells toward chemotherapeutics seems to be dependent on $\mathrm{Ca}^{2+}$ fluxes at the MAMs (Kerkhofs et al. 2018). These insights offer novel opportunities to promote cancer cell death, for example through novel peptide tools that act at the MAM interface (Kerkhofs et al. 2019).

Triggering of $\mathrm{Ca}^{2+}$-induced $\mathrm{Ca}^{2+}$ release (Fig. 5D) can occur when $\mathrm{Ca}^{2+}$ channels are in close proximity. As mentioned above, $\mathrm{IP}_{3} \mathrm{Rs}$ and RyRs are activated by an increase in the cytosolic $\mathrm{Ca}^{2+}$ concentration (Bezprozvanny et al. 1991). Both types of channel have been shown to amplify small $\mathrm{Ca}^{2+}$ signals into much larger responses via $\mathrm{Ca}^{2+}$-induced $\mathrm{Ca}^{2+}$ release. This amplification is critical for relatively small $\mathrm{Ca}^{2+}$ stores such as lysosomes to trigger substantial cellular $\mathrm{Ca}^{2+}$ signals (Galione 2019). For example, the cellular messenger nicotinamide adenine dinucleotide phosphate can cause a limited release of $\mathrm{Ca}^{2+}$ from lysosomes via TPCs (LloydEvans and Waller-Evans 2019), which can then be amplified by $\mathrm{IP}_{3} \mathrm{Rs}$ and RyRs (Zhu et al. 2010). $\mathrm{IP}_{3}$ Rs have been found to be strategically located within ER-lysosomal contact sites (Atakpa et al. 2018), where they serve to deliver
$\mathrm{Ca}^{2+}$ from the ER to the lysosomal compartment (Patel 2019).

\section{CONCLUDING REMARKS}

Cellular $\mathrm{Ca}^{2+}$ signaling is complex, multifactorial, and dynamic, and is critical to many physiological processes. $\mathrm{Ca}^{2+}$ signals can arise from a number of sources and via a plethora of channels and other transporters. $\mathrm{Ca}^{2+}$ signaling is tightly integrated with other cellular signal transduction pathways, and there are many examples of cross talk and synergy. Cellular signaling can remodel depending on environmental conditions, and alterations to $\mathrm{Ca}^{2+}$ signals or $\mathrm{Ca}^{2+}$ homeostasis occur in disease conditions. The discussion above is a necessarily superficial tour of some of the key aspects of cellular $\mathrm{Ca}^{2+}$ signaling. For each of the topics discussed, there is a wealth of underlying publications and knowledge. The intention of this article was to stimulate appreciation of $\mathrm{Ca}^{2+}$ signaling so that the interested enquirer might continue reading. Fortunately, while the $\mathrm{Ca}^{2+}$ signaling literature is vast, there are some underpinning principles of $\mathrm{Ca}^{2+}$ signaling that apply irrespective of the cell type and its function. In particular, $\mathrm{Ca}^{2+}$ signals are highly organized in terms of kinetics and cellular location. The organization of $\mathrm{Ca}^{2+}$ signals enables cells to use $\mathrm{Ca}^{2+}$ as a means of simultaneously controlling diverse processes. It is clear that perturbations of $\mathrm{Ca}^{2+}$ signaling are a proximal factor in the pathogenesis of debilitating and fatal pathologies, but our increasing understanding of aberrant $\mathrm{Ca}^{2+}$ signals offers unprecedented opportunities for novel therapeutic strategies.

\section{REFERENCES}

${ }^{*}$ Reference is also in this collection.

* Ahuja M, Young Chung W, Lin W-Y, McNally BA, Muallem S. 2019. $\mathrm{Ca}^{2+}$ signaling in exocrine cells. Cold Spring Harb Perspect Biol doi:10.1101/cshperspect.a035279

Ambudkar IS, de Souza LB, Ong HL. 2017. TRPC1, Orail, and STIM1 in SOCE: Friends in tight spaces. Cell Calcium 63: 33-39. doi:10.1016/j.ceca.2016.12.009

Atakpa P, Thillaiappan NB, Mataragka S, Prole DL, Taylor CW. 2018. IP3 receptors preferentially associate with ER-lysosome contact sites and selectively deliver $\mathrm{Ca}^{2+}$ 
to lysosomes. Cell Rep 25: 3180-3193.e7. doi:10.1016/j .celrep.2018.11.064

* Barak P, Parekh AB. 2019. Signaling through $\mathrm{Ca}^{2+}$ microdomains from store-operated CRAC channels. Cold Spring Harb Perspect Biol doi:10.1101/cshperspect.a035097

Berridge MJ. 1997. The AM and FM of calcium signalling. Nature 386: 759-760. doi:10.1038/386759a0

Berridge MJ. 2006. Calcium microdomains: Organization and function. Cell Calcium 40: 405-412. doi:10.1016/j .ceca.2006.09.002

Berridge MJ. 2012. Calcium signalling remodelling and disease. Biochem Soc Trans 40: 297-309. doi:10.1042/ BST20110766

Berridge MJ. 2017. Calcium signalling in health and disease. Biochem Biophys Res Commun 485: 5. doi:10.1016/j.bbrc .2017.01.098

Berridge MJ, Galione A. 1988. Cytosolic calcium oscillators. FASEB J 2: 3074-3082. doi:10.1096/fasebj.2.15.2847949

Berridge MJ, Rapp PE. 1979. A comparative survey of the function, mechanism and control of cellular oscillators. $J$ Exp Biol 81: 217-279.

Berridge MJ, Lipp P, Bootman MD. 2000. The versatility and universality of calcium signalling. Nat Rev Mol Cell Biol 1: 11-21. doi:10.1038/35036035

Bers DM. 2002. Cardiac excitation-contraction coupling. Nature 415: 198-205. doi:10.1038/415198a

Bers DM. 2008. Calcium cycling and signaling in cardiac myocytes. Annu Rev Physiol 70: 23-49. doi:10.1146/an nurev.physiol.70.113006.100455

Bers DM, Guo T. 2005. Calcium signaling in cardiac ventricular myocytes. Ann NY Acad Sci 1047: 86-98. doi:10 $.1196 /$ annals. 1341.008

Bezprozvanny I, Watras J, Ehrlich BE. 1991. Bell-shaped calcium-response curves of $\operatorname{lns}(1,4,5) \mathrm{P} 3$ - and calciumgated channels from endoplasmic reticulum of cerebellum. Nature 351: 751-754. doi:10.1038/351751a0

* Bhattacharyya M, Karandur D, Kuriyan J. 2019. Structural insights into the regulation of $\mathrm{Ca}^{2+} /$ calmodulin-dependent protein kinase II (CaMKII). Cold Spring Harb Perspect Biol doi:10.1101/cshperspect.a035147

Booth DM, Enyedi B, Geiszt M, Várnai P, Hajnóczky G. 2016. Redox nanodomains are induced by and control calcium signaling at the ER-mitochondrial interface. Mol Cell 63: 240-248. doi:10.1016/j.molcel.2016.05.040

Bootman MD, Young KW, Young JM, Moreton RB, Berridge MJ. 1996. Extracellular calcium concentration controls the frequency of intracellular calcium spiking independently of inositol 1,4,5-trisphosphate production in HeLa cells. Biochem J 314: 347-354. doi:10.1042/ bj3140347

Bootman M, Niggli E, Berridge M, Lipp P. 1997. Imaging the hierarchical $\mathrm{Ca}^{2+}$ signaling system in HeLa cells. J Physiol 499: 307-314. doi:10.1113/jphysiol.1997.sp021928

Bootman MD, Lipp P, Berridge MJ. 2001. The organisation and functions of local $\mathrm{Ca}^{2+}$ signals. J Cell Sci 114: 22132222.

Bootman MD, Fearnley C, Smyrnias I, MacDonald F, Roderick HL. 2009. An update on nuclear calcium signalling. $J$ Cell Sci 122: 2337-2350. doi:10.1242/jcs.028100
Bootman MD, Rietdorf K, Collins T, Walker S, Sanderson M. 2013. $\mathrm{Ca}^{2+}$-sensitive fluorescent dyes and intracellular $\mathrm{Ca}^{2+}$ imaging. Cold Spring Harb Protoc 2013: 83-99.

Bootman MD, Chehab T, Bultynck G, Parys JB, Rietdorf K. 2018. The regulation of autophagy by calcium signals: Do we have a consensus? Cell Calcium 70: 32-46. doi:10 .1016/j.ceca.2017.08.005

* Burgoyne RD, Helassa N, McCue HV, Haynes LP. 2019. Calcium sensors in neuronal function and dysfunction. Cold Spring Harb Perspect Biol 11: a035154. doi:10.1101/ cshperspect.a035154

Callamaras N, Marchant JS, Sun XP, Parker I. 1998. Activation and co-ordination of Ins $P_{3}$-mediated elementary $\mathrm{Ca}^{2+}$ events during global $\mathrm{Ca}^{2+}$ signals in Xenopus oocytes. J Physiol 509: 81-91. doi:10.1111/j.1469-7793.19 98.081bo.x

Cárdenas C, Miller RA, Smith I, Bui T, Molgó J, Müller M, Vais H, Cheung KH, Yang J, Parker I, et al. 2010. Essential regulation of cell bioenergetics by constitutive $\mathrm{InsP}_{3}$ receptor $\mathrm{Ca}^{2+}$ transfer to mitochondria. Cell 142: 270-283. doi:10.1016/j.cell.2010.06.007

* Chen J, Sitsel A, Benoy V, Sepúlveda MR, Vangheluwe P. 2019. Primary active $\mathrm{Ca}^{2+}$ transport systems in health and disease. Cold Spring Harb Persepct Biol doi:10.1101/ cshperspect.a035113.

Cheng KT, Liu X, Ong HL, Swaim W, Ambudkar IS. 2011. Local $\mathrm{Ca}^{2+}$ entry via Orail regulates plasma membrane recruitment of TRPC1 and controls cytosolic $\mathrm{Ca}^{2+}$ signals required for specific cell functions. PLoS Biol 9: e1001025. doi:10.1371/journal.pbio.1001025

Ciccolini F, Collins TJ, Sudhoelter J, Lipp P, Berridge MJ, Bootman MD. 2003. Local and global spontaneous calcium events regulate neurite outgrowth and onset of GABAergic phenotype during neural precursor differentiation. J Neurosci 23: 103-111. doi:10.1523/jneurosci.2301-00103.2003

Clapham DE. 2007. Calcium signaling. Cell 131: 1047-1058. doi:10.1016/j.cell.2007.11.028

Collins TJ, Lipp P, Berridge MJ, Bootman MD. 2001. Mitochondrial $\mathrm{Ca}^{2+}$ uptake depends on the spatial and temporal profile of cytosolic $\mathrm{Ca}^{2+}$ signals. J Biol Chem 276: 26411-26420. doi:10.1074/jbc.M101101200

Csordás G, Thomas AP, Hajnóczky G. 1999. Quasi-synaptic calcium signal transmission between endoplasmic reticulum and mitochondria. $E M B O J$ 18: 96-108. doi:10 $.1093 / \mathrm{emboj} / 18.1 .96$

Csordás G, Weaver D, Hajnóczky G. 2018. Endoplasmic reticulum-mitochondrial contactology: Structure and signaling functions. Trends Cell Biol 28: 523-540. doi:10 $.1016 /$ j.tcb.2018.02.009

Dellis O, Dedos SG, Tovey SC, Taufiq Ur R, Dubel SJ, Taylor CW. 2006. $\mathrm{Ca}^{2+}$ entry through plasma membrane $\mathrm{IP}_{3}$ receptors. Science 313: 229-233. doi:10.1126/science .1125203

Demuro A, Parker I. 2006. Imaging single-channel calcium microdomains. Cell Calcium 40: 413-422. doi:10.1016/j .ceca.2006.08.006

Desai PN, Zhang X, Wu S, Janoshazi A, Bolimuntha S, Putney JW, Trebak M. 2015. Multiple types of calcium channels arising from alternative translation initiation of the Orail message. Sci Signal 8: ra74. doi:10.1126/scisignal .aaa8323 
M.D. Bootman and G. Bultynck

* Distelhorst CW, Bootman MD. 2019. Creating a new cancer therapeutic agent by targeting the interaction between Bcl-2 and $\mathrm{IP}_{3}$ receptors. Cold Spring Harb Perspect Biol doi:10.1101/cshperspect.a035196

Dolgin E. 2019. How secret conversations inside cells are transforming biology. Nature 567: 162-164. doi:10 .1038/d41586-019-00792-9

Dolmetsch RE, Lewis RS, Goodnow CC, Healy JI. 1997. Differential activation of transcription factors induced by $\mathrm{Ca}^{2+}$ response amplitude and duration. Nature 386: 855-858. doi:10.1038/386855a0

Dolmetsch RE, Xu K, Lewis RS. 1998. Calcium oscillations increase the efficiency and specificity of gene expression. Nature 392: 933-936. doi:10.1038/31960

Dupont G, Combettes L, Bird GS, Putney JW. 2011. Calcium oscillations. Cold Spring Harb Perspect Biol 3: a004226. doi:10.1101/cshperspect.a004226

Eisner DA, Caldwell JL, Kistamás K, Trafford AW. 2017. Calcium and excitation-contraction coupling in the heart. Circ Res 121: 181-195. doi:10.1161/circresaha.117 .310230

Fan G, Baker ML, Wang Z, Baker MR, Sinyagovskiy PA, Chiu W, Ludtke SJ, Serysheva II. 2015. Gating machinery of InsP3R channels revealed by electron cryomicroscopy. Nature 527: 336-341. doi:10.1038/nature15249

Fan G, Baker MR, Wang Z, Seryshev AB, Ludtke SJ, Baker ML, Serysheva II. 2018. Cryo-EM reveals ligand induced allostery underlying InsP3R channel gating. Cell Res 28: 1158-1170. doi:10.1038/s41422-018-0108-5

Fearnley CJ, Roderick HL, Bootman MD. 2011. Calcium signaling in cardiac myocytes. Cold Spring Harb Perspect Biol 3: a004242. doi:10.1101/cshperspect.a004242

Foskett JK, White C, Cheung KH, Mak DO. 2007. Inositol trisphosphate receptor $\mathrm{Ca}^{2+}$ release channels. Physiol Rev 87: 593-658. doi:10.1152/physrev.00035.2006

* Galione A. 2019. NAADP receptors. Cold Spring Harb Perspect Biol doi:10.1101/cshperspect.a035071

Galione A, Churchill GC. 2000. Cyclic ADP ribose as a calcium-mobilizing messenger. Sci STKE 2000: pe1. doi:10 .1126/stke.2000.18.pe1

* Gilbert G, Demydenko K, Dries E, Puertas RD, Jin X Sipido K, Roderick HL. 2019. Calcium signaling in cardiomyocyte function. Cold Spring Harb Perspect Biol doi:10.1101/ cshperspect.a035428

Giorgi C, Danese A, Missiroli S, Patergnani S, Pinton P. 2018a. Calcium dynamics as a machine for decoding signals. Trends Cell Biol 28: 258-273. doi:10.1016/j.tcb.2018 .01 .002

Giorgi C, Marchi S, Pinton P. 2018b. The machineries, regulation and cellular functions of mitochondrial calcium. Nat Rev Mol Cell Biol 19: 713-730. doi:10.1038/s41580018-0052-8

Granatiero V, De Stefani D, Rizzuto R. 2017. Mitochondrial calcium handling in physiology and disease. Adv Exp Med Biol 982: 25-47. doi:10.1007/978-3-319-55330-6_2

Hagenston AM, Bading H. 2011. Calcium signaling in synapse-to-nucleus communication. Cold Spring Harb Perspect Biol 3: a004564. doi:10.1101/cshperspect.a004564

* Hagenston AM, Bading H, Bas-Orth C. 2019. Functional consequences of calcium-dependent synapse-to-nucleus communication: Focus on transcription-dependent met- abolic plasticity. Cold Spring Harb Perspect Biol doi:10 .1101/cshperspect.a035287

Hajnóczky G, Robb-Gaspers LD, Seitz MB, Thomas AP. 1995. Decoding of cytosolic calcium oscillations in the mitochondria. Cell 82: 415-424. doi:10.1016/0092-8674 (95)90430-1

Hamada K, Miyatake H, Terauchi A, Mikoshiba K. 2017. $\mathrm{IP}_{3}$-mediated gating mechanism of the $\mathrm{IP}_{3}$ receptor revealed by mutagenesis and X-ray crystallography. Proc Natl Acad Sci 114: 4661-4666. doi:10.1073/pnas .1701420114

Harzheim D, Movassagh M, Foo RS, Ritter O, Tashfeen A, Conway SJ, Bootman MD, Roderick HL. 2009. Increased InsP3Rs in the junctional sarcoplasmic reticulum augment $\mathrm{Ca}^{2+}$ transients and arrhythmias associated with cardiac hypertrophy. Proc Natl Acad Sci 106: 1140611411. doi:10.1073/pnas.0905485106

Heinzel FR, MacQuaide N, Biesmans L, Sipido K. 2011. Dyssynchrony of $\mathrm{Ca}^{2+}$ release from the sarcoplasmic reticulum as subcellular mechanism of cardiac contractile dysfunction. J Mol Cell Cardiol 50: 390-400. doi:10.1016/j .yjmcc.2010.11.008

Higazi DR, Fearnley CJ, Drawnel FM, Talasila A, Corps EM, Ritter O, McDonald F, Mikoshiba K, Bootman MD, Roderick HL. 2009. Endothelin-1-stimulated $\mathrm{InsP}_{3}$-induced $\mathrm{Ca}^{2+}$ release is a nexus for hypertrophic signaling in cardiac myocytes. Mol Cell 33: 472-482. doi:10.1016/j .molcel.2009.02.005

Hoth M, Penner R. 1992. Depletion of intracellular calcium stores activates a calcium current in mast cells. Nature 355: 353-356. doi:10.1038/355353a0

Humeau J, Bravo-San Pedro JM, Vitale I, Nuñez L, Villalobos C, Kroemer G, Senovilla L. 2018. Calcium signaling and cell cycle: Progression or death. Cell Calcium 70: $3-$ 15. doi:10.1016/j.ceca.2017.07.006

Hüser J, Blatter LA, Lipsius SL. 2000. Intracellular $\mathrm{Ca}^{2+}$ release contributes to automaticity in cat atrial pacemaker cells. J Physiol 524: 415-422. doi:10.1111/j.1469-7793 .2000.00415.x

* Ivanova H, Vervliet T, Monaco G, Terry LE, Rosa N, Baker MR, Parys JB, Serysheva II, Yule DI, Bultynck G. 2019. Bcl-2 protein family as modulators of $\mathrm{IP}_{3}$ receptors and other organeller $\mathrm{Ca}^{2+}$ channels. Cold Spring Harb Perspect Biol doi:10.1101/cshperspect.a035089

Joseph SK, Booth DM, Young MP, Hajnóczky G. 2019. Redox regulation of ER and mitochondrial $\mathrm{Ca}^{2+}$ signaling in cell survival and death. Cell Calcium 79: 89-97. doi:10 .1016/j.ceca.2019.02.006

Kerkhofs M, Giorgi C, Marchi S, Seitaj B, Parys JB, Pinton P, Bultynck G, Bittremieux M. 2017. Alterations in $\mathrm{Ca}^{2+}$ signalling via ER-mitochondria contact site remodelling in cancer. Adv Exp Med Biol 997: 225-254. doi:10.1007/ 978-981-10-4567-7_17

Kerkhofs M, Bittremieux M, Morciano G, Giorgi C, Pinton P, Parys JB, Bultynck G. 2018. Emerging molecular mechanisms in chemotherapy: $\mathrm{Ca}^{2+}$ signaling at the mitochondria-associated endoplasmic reticulum membranes. Cell Death Dis 9: 334. doi:10.1038/s41419-017-0179-0

Kerkhofs M, Bultynck G, Vervliet T, Monaco G. 2019. Therapeutic implications of novel peptides targeting ER-mitochondria $\mathrm{Ca}^{2+}$-flux systems. Drug Discov Today 24: 1092-1103. doi:10.1016/j.drudis.2019.03.020 
Kirichok Y, Krapivinsky G, Clapham DE. 2004. The mitochondrial calcium uniporter is a highly selective ion channel. Nature 427: 360-364. doi:10.1038/nature02246

Kockskämper J, Sheehan KA, Bare DJ, Lipsius SL, Mignery GA, Blatter LA. 2001. Activation and propagation of $\mathrm{Ca}^{2+}$ release during excitation-contraction coupling in atrial myocytes. Biophys J 81: 2590-2605. doi:10.1016/S00063495(01)75903-6

Lanner JT, Georgiou DK, Joshi AD, Hamilton SL. 2010. Ryanodine receptors: Structure, expression, molecular details, and function in calcium release. Cold Spring Harb Perspect Biol 2: a003996. doi:10.1101/cshperspect .a003996

La Rovere RM, Roest G, Bultynck G, Parys JB. 2016. Intracellular $\mathrm{Ca}^{2+}$ signaling and $\mathrm{Ca}^{2+}$ microdomains in the control of cell survival, apoptosis and autophagy. Cell Calcium 60: 74-87. doi:10.1016/j.ceca.2016.04.005

* Lewis RS. 2019. Store-operated calcium channels: From function to structure and back again. Cold Spring Harb Perspect Biol doi:10.1101/cshperspect.a035055

Liou J, Kim ML, Heo WD, Jones JT, Myers JW, Ferrel JE Jr, Meyer T. 2005. STIM is a $\mathrm{Ca}^{2+}$ sensor essential for $\mathrm{Ca}^{2+}$-store-depletion-triggered $\mathrm{Ca}^{2+}$ influx. Curr Biol 15: 1235-1241. doi:10.1016/j.cub.2005.05.055

Lipp P, Reither G. 2011. Protein kinase C: the "masters" of calcium and lipid. Cold Spring Harb Perspect Biol 3: a004556. doi:10.1101/cshperspect.a004556

Lipp P, Thomas D, Berridge MJ, Bootman MD. 1997. Nuclear calcium signalling by individual cytoplasmic calcium puffs. EMBO J 16: 7166-7173. doi:10.1093/emboj/16 .23 .7166

* Lloyd-Evans E, Waller-Evans H. 2019. Lysosomal $\mathrm{Ca}^{2+}$ homeostasis and signaling in health and disease. Cold Spring Harb Perspect Biol doi:10.1101/cshperspect.a035311

Louch WE, Bito V, Heinzel FR, Macianskiene R, Vanhaecke J, Flameng W, Mubagwa K, Sipido KR. 2004. Reduced synchrony of $\mathrm{Ca}^{2+}$ release with loss of T-tubules-A comparison to $\mathrm{Ca}^{2+}$ release in human failing cardiomyocytes. Cardiovasc Res 62: 63-73. doi:10.1016/j.cardiores.2003 .12 .031

Mackenzie L, Roderick HL, Berridge MJ, Conway SJ, Bootman MD. 2004. The spatial pattern of atrial cardiomyocyte calcium signalling modulates contraction. J Cell Sci 117: 6327-6337. doi:10.1242/jcs.01559

Mammucari C, Gherardi G, Rizzuto R. 2017. Structure, activity regulation, and role of the mitochondrial calcium uniporter in health and disease. Front Oncol 7: 139. doi:10 $.3389 /$ fonc. 2017.00139

Mammucari C, Raffaello A, Vecellio Reane D, Gherardi G, De Mario A, Rizzuto R. 2018. Mitochondrial calcium uptake in organ physiology: From molecular mechanism to animal models. Pflugers Arch 470: 1165-1179. doi:10 .1007/s00424-018-2123-2

* Marchant JS. 2019. $\mathrm{Ca}^{2+}$ signaling and regeneration. Cold Spring Harb Perspect Biol doi:10.1101/cshperspect .a035485

Marchi S, Patergnani S, Missiroli S, Morciano G, Rimessi A, Wieckowski MR, Giorgi C, Pinton P. 2018. Mitochondrial and endoplasmic reticulum calcium homeostasis and cell death. Cell Calcium 69: 62-72. doi:10.1016/j.ceca.2017.05 .003
Mattson MP, Taylor-Hunter A, Kater SB. 1988. Neurite outgrowth in individual neurons of a neuronal population is differentially regulated by calcium and cyclic AMP. J Neurosci 8: 1704-1711. doi:10.1523/jneurosci.08-05-01704 .1988

Mekahli D, Bultynck G, Parys JB, De Smedt H, Missiaen L. 2011. Endoplasmic-reticulum calcium depletion and disease. Cold Spring Harb Perspect Biol 3: a004317. doi:10 $.1101 /$ cshperspect.a004317

Mikoshiba K. 2015. Role of IP3 receptor signaling in cell functions and diseases. Adv Biol Regul 57: 217-227. doi:10.1016/j.jbior.2014.10.001

* Ong HL, Ambudkar IS. 2019. The endoplasmic reticulumplasma membrane junction: A hub for agonist regulation of $\mathrm{Ca}^{2+}$ entry. Cold Spring Harb Perspect Biol doi:10.1101/ cshperspect.a035253

Orrenius S, Zhivotovsky B, Nicotera P. 2003. Regulation of cell death: The calcium-apoptosis link. Nat Rev Mol Cell Biol 4: 552-565. doi:10.1038/nrm1150

Parys JB, Bultynck G. 2018. Calcium signaling in health, disease and therapy. Biochim Biophys Acta Mol Cell Res 1865: 1657-1659. doi:10.1016/j.bbamcr.2018.08.019

Patel S. 2019. Getting close. Lysosome-ER contact sites tailor $\mathrm{Ca}^{2+}$ signals. Cell Calcium 80: 194-196. doi:10.1016/j .ceca.2019.02.003

Penna E, Espino J, De Stefani D, Rizzuto R. 2018. The MCU complex in cell death. Cell Calcium 69: 73-80. doi:10 $.1016 /$ j.ceca.2017.08.008

Prakriya M, Feske S, Gwack Y, Srikanth S, Rao A, Hogan PG. 2006. Orail is an essential pore subunit of the CRAC channel. Nature 443: 230-233. doi:10.1038/nature05122

* Prole DL, Taylor CW. 2019. Structure and function of $\mathrm{IP}_{3}$ receptors. Cold Spring Harb Perspect Biol 11: a035063. doi:10.1101/cshperspect.a035063

* Proudfoot D. 2019. Calcium signaling and tissue calcification. Cold Spring Harb Perspect Biol doi:10.1101/cshper spect.a035303

Putney JW Jr. 1990. Capacitative calcium entry revisited. Cell Calcium 11: 611-624. doi:10.1016/0143-4160(90) 90016-N

Raffaello A, Mammucari C, Gherardi G, Rizzuto R. 2016. Calcium at the center of cell signaling: Interplay between endoplasmic reticulum, mitochondria, and lysosomes. Trends Biochem Sci 41: 1035-1049. doi:10.1016/j.tibs .2016.09.001

Rizzuto R, Brini M, Murgia M, Pozzan T. 1993. Microdomains with high $\mathrm{Ca}^{2+}$ close to $\mathrm{IP}_{3}$-sensitive channels that are sensed by neighboring mitochondria. Science 262: 744-747. doi:10.1126/science.8235595

Rizzuto R, Pinton P, Carrington W, Fay FS, Fogarty KE, Lifshitz LM, Tuft RA, Pozzan T. 1998. Close contacts with the endoplasmic reticulum as determinants of mitochondrial $\mathrm{Ca}^{2+}$ responses. Science 280: 1763-1766.

* Roberts-Thomson SJ, Chalmers SB, Monteith GR. 2019. The calcium signaling toolkit in cancer: Remodeling and targeting. Cold Spring Harb Perspect Biol doi:10.1101/cshper spect.a035204

Roderick HL, Berridge MJ, Bootman MD. 2003. Calciuminduced calcium release. Curr Biol 13: R425. doi:10.1016/ S0960-9822(03)00358-0 
M.D. Bootman and G. Bultynck

Roderick HL, Higazi DR, Smyrnias I, Fearnley C, Harzheim D, Bootman MD. 2007. Calcium in the heart: When it's good, it's very very good, but when it's bad, it's horrid. Biochem Soc Trans 35: 957-961. doi:10.1042/ BST0350957

Rooney TA, Sass EJ, Thomas AP. 1989. Characterization of cytosolic calcium oscillations induced by phenylephrine and vasopressin in single fura-2-loaded hepatocytes. $J$ Biol Chem 264: 17131-17141.

Rossi A, Pizzo P, Filadi R. 2019. Calcium, mitochondria and cell metabolism: A functional triangle in bioenergetics. Biochim Biophys Acta Mol Cell Res 1866: 1068-1078. doi:10.1016/j.bbamcr.2018.10.016

* Roy J, Cyert MS. 2019. Identifying new substrates and functions for an old enzyme: Calcineurin. Cold Spring Harb Perspect Biol doi:10.1101/cshperspect.a035436

Santulli G, Lewis DR, Marks AR. 2017. Physiology and pathophysiology of excitation-contraction coupling: The functional role of ryanodine receptor. J Muscle Res Cell Motil 38: 37-45. doi:10.1007/s10974-017-9470-z

Schwaller B. 2010. Cytosolic $\mathrm{Ca}^{2+}$ buffers. Cold Spring Harb Perspect Biol 2: a004051. doi:10.1101/cshperspect .a004051

* Schwaller B. 2019. Cytosolic $\mathrm{Ca}^{2+}$ buffers are inherently $\mathrm{Ca}^{2+}$ signal modulators. Cold Spring Harb Perspect Biol doi:10 $.1101 /$ cshperspect.a035543

Scorrano L, De Matteis MA, Emr S, Giordano F, Hajnóczky G, Kornmann B, Lackner LL, Levine TP, Pellegrini L, Reinisch K, et al. 2019. Coming together to define membrane contact sites. Nat Commun 10: 1287. doi:10.1038/ s41467-019-09253-3

Skupin A, Kettenmann H, Winkler U, Wartenberg M, Sauer H, Tovey SC, Taylor CW, Falcke M. 2008. How does intracellular $\mathrm{Ca}^{2+}$ oscillate: By chance or by the clock? Biophys J 94: 2404-2411. doi:10.1529/biophysj .107 .119495

Smith IF, Shuai J, Parker I. 2011. Active generation and propagation of $\mathrm{Ca}^{2+}$ signals within tunneling membrane nanotubes. Biophys J 100: L37-L39. doi:10.1016/j.bpj .2011 .03 .007

Soboloff J, Romanin C. 2019. STIM1 structure-function and downstream signaling pathways. Cell Calcium 80: 101102. doi:10.1016/j.ceca.2019.01.004

Szabadkai G, Bianchi K, Várnai P, De Stefani D, Wieckowski MR, Cavagna D, Nagy AI, Balla T, Rizzuto R. 2006. Chaperone-mediated coupling of endoplasmic reticulum and mitochondrial $\mathrm{Ca}^{2+}$ channels. J Cell Biol 175: 901-911. doi:10.1083/jcb.200608073

Thul R, Falcke M. 2004. Release currents of $\mathrm{IP}_{3}$ receptor channel clusters and concentration profiles. Biophys $J$ 86: 2660-2673. doi:10.1016/S0006-3495(04)74322-2

Thul R, Smith GD, Coombes S. 2008. A bidomain threshold model of propagating calcium waves. J Math Biol 56: 435463. doi:10.1007/s00285-007-0123-5

Vandecaetsbeek I, Vangheluwe P, Raeymaekers L, Wuytack F, Vanoevelen J. 2011. The $\mathrm{Ca}^{2+}$ pumps of the endoplasmic reticulum and Golgi apparatus. Cold Spring
Harb Perspect Biol 3: a004184. doi:10.1101/cshperspect .a004184

* Vangeel L, Voets T. 2019. Transient receptor potential (TRP) channels and calcium signaling. Cold Spring Harb Perspect Biol doi:10.1101/cshperspect.a035048

Vergun O, Keelan J, Khodorov BI, Duchen MR. 1999. Glutamate-induced mitochondrial depolarisation and perturbation of calcium homeostasis in cultured rat hippocampal neurones. J Physiol 519: 451-466. doi:10.1111/j $.1469-7793.1999 .0451 \mathrm{~m} . \mathrm{x}$

* Verkhratsky A. 2019. Astroglial calcium signaling in aging and Alzheimer's disease. Cold Spring Harb Perspect Biol doi:10.1101/cshperspect.a035188

Vervliet T, Parys JB, Bultynck. 2016. Bcl-2 proteins and calcium signaling: Complexity beneath the surface. Oncogene 35: 5079-5092. doi:10.1038/onc.2016.31

* Wacquier B, Combettes L, Dupont G. 2019. Cytoplasmic and mitochondrial calcium signaling: A two-way relationship. Cold Spring Harb Perspect Biol doi:10.1101/cshperspect .a035139

* Wakai T, Mehregan A, Fissore RA. 2019. Ca ${ }^{2+}$ signaling and homeostasis in mammalian oocytes and eggs. Cold Spring Harb Perspect Biol doi:10.1101/cshperspect.a035162

Walter L, Hajnóczky G. 2005. Mitochondria and endoplasmic reticulum: The lethal interorganelle cross-talk. J Bioenerg Biomembr 37: 191-206. doi:10.1007/s10863-005$6600-\mathrm{x}$

* Wang W-A, Agellon LB, Michalak M. 2019. Organellar calcium handling in the cellular reticular network. Cold Spring Harb Perspect Biol doi:10.1101/cshperspect .a038265

* Webb SE, Kelu JJ, Miller AL. 2019. Role of two-pore channels in embryonic development and cellular differentiation. Cold Spring Harb Perspect Biol doi:10.1101/cshper spect.a035170

Woods NM, Cuthbertson KS, Cobbold PH. 1986. Repetitive transient rises in cytoplasmic free calcium in hormonestimulated hepatocytes. Nature 319: 600-602. doi:10 $.1038 / 319600 \mathrm{a} 0$

Yao Y, Choi J, Parker I. 1995. Quantal puffs of intracellular $\mathrm{Ca}^{2+}$ evoked by inositol trisphosphate in Xenopus oocytes. J Physiol 482: 533-553. doi:10.1113/jphysiol.1995 .sp020538

Zhang SL, Yu Y, Roos J, Kozak JA, Deerinck TJ, Ellisman MH, Stauderman KA, Cahalan MD. 2005. STIM1 is a $\mathrm{Ca}^{2+}$ sensor that activates CRAC channels and migrates from the $\mathrm{Ca}^{2+}$ store to the plasma membrane. Nature 437: $902-$ 905. doi:10.1038/nature04147

Zhou Y, Cai X, Nwokonko RM, Loktionova NA, Wang Y, Gill DL. 2017. The STIM-Orai coupling interface and gating of the Orail channel. Cell Calcium 63: 8-13. doi:10.1016/j.ceca.2017.01.001

Zhu MX, Ma J, Parrington J, Calcraft PJ, Galione A, Evans AM. 2010. Calcium signaling via two-pore channels: Local or global, that is the question. Am J Physiol Cell Physiol 298: C430-C441. doi:10.1152/ajpcell.00475.2009 


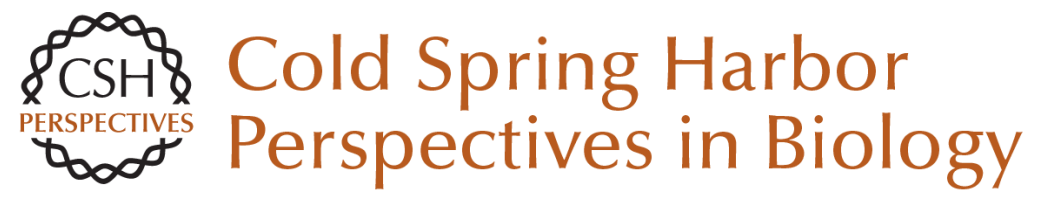

\section{Fundamentals of Cellular Calcium Signaling: A Primer}

Martin D. Bootman and Geert Bultynck

Cold Spring Harb Perspect Biol 2020; doi: 10.1101/cshperspect.a038802 originally published online August 19, 2019

\section{Subject Collection Calcium Signaling}

The Endoplasmic Reticulum-Plasma Membrane Junction: A Hub for Agonist Regulation of $\mathrm{Ca}^{2+}$ Entry

Hwei Ling Ong and Indu Suresh Ambudkar

Calcium-Handling Defects and Neurodegenerative Disease

Sean Schrank, Nikki Barrington and Grace E. Stutzmann

Lysosomal $\mathrm{Ca}^{2+}$ Homeostasis and Signaling in Health and Disease

Emyr Lloyd-Evans and Helen Waller-Evans

\section{$\mathrm{Ca}^{2+}$ Signaling in Exocrine Cells}

Malini Ahuja, Woo Young Chung, Wei-Yin Lin, et al.

Functional Consequences of Calcium-Dependent Synapse-to-Nucleus Communication: Focus on Transcription-Dependent Metabolic Plasticity Anna M. Hagenston, Hilmar Bading and Carlos Bas-Orth

Identifying New Substrates and Functions for an Old Enzyme: Calcineurin Jagoree Roy and Martha S. Cyert

Fundamentals of Cellular Calcium Signaling: A Primer

Martin D. Bootman and Geert Bultynck
Primary Active $\mathrm{Ca}^{2+}$ Transport Systems in Health and Disease Jialin Chen, Aljona Sitsel, Veronick Benoy, et al.

Signaling through $\mathrm{Ca}^{2+}$ Microdomains from Store-Operated CRAC Channels Pradeep Barak and Anant B. Parekh

Structural Insights into the Regulation of $\mathrm{Ca}^{2+}$ /Calmodulin-Dependent Protein Kinase II (CaMKII) Moitrayee Bhattacharyya, Deepti Karandur and John Kuriyan

Store-Operated Calcium Channels: From Function to Structure and Back Again Richard S. Lewis

$\mathrm{Bcl}-2-P r o t e i n$ Family as Modulators of $\mathrm{IP}_{3}$

Receptors and Other Organellar $\mathrm{Ca} 2+$ Channels Hristina Ivanova, Tim Vervliet, Giovanni Monaco, et al.

Calcium Signaling in Cardiomyocyte Function Guillaume Gilbert, Kateryna Demydenko, Eef Dries, et al.

Cytosolic $\mathrm{Ca}^{2+}$ Buffers Are Inherently $\mathrm{Ca}^{2+}$ Signal Modulators Beat Schwaller

For additional articles in this collection, see http://cshperspectives.cshlp.org/cgi/collection/

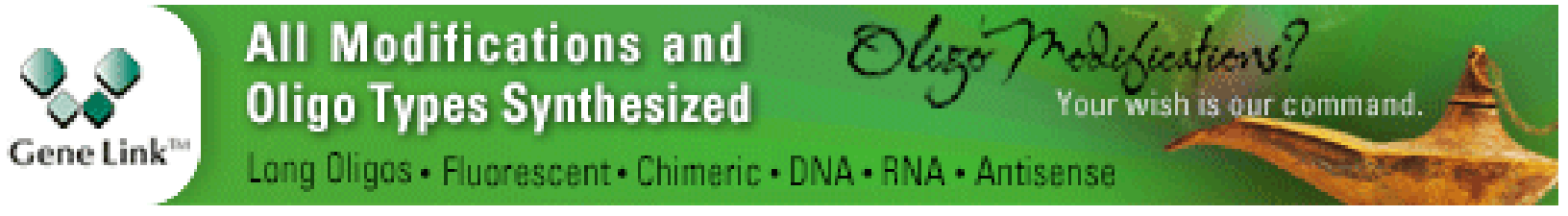


Role of Two-Pore Channels in Embryonic Development and Cellular Differentiation Sarah E. Webb, Jeffrey J. Kelu and Andrew L. Miller

\section{Organellar Calcium Handling in the Cellular \\ Reticular Network}

Wen-An Wang, Luis B. Agellon and Marek Michalak

For additional articles in this collection, see http://cshperspectives.cshlp.org/cgi/collection/

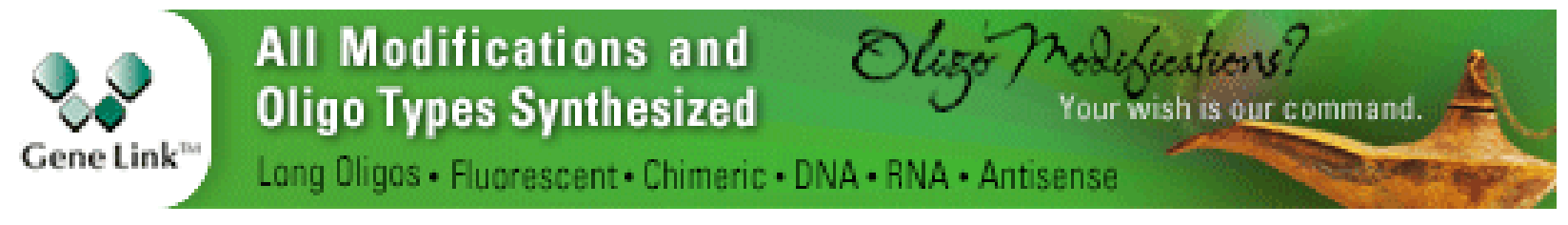

Copyright @ 2020 Cold Spring Harbor Laboratory Press; all rights reserved 